Studia Judaica 23 (2020), nr 1 (45), s. 169-201

doi:10.4467/24500100STJ.20.006.12920

Piotr Sewruk (D) https://orcid.org/0000-0002-0459-9765

\title{
Rzemiosło żydowskie w Lublinie i jego instytucje w latach trzydziestych XX wieku
}

\author{
JEWISH CRAFTS IN LUBLIN AND THEIR INSTITUTIONS IN THE 1930s
}

\begin{abstract}
The paper attempts to reconstruct the condition of Jewish crafts in Lublin in the 1930s after the new legal regulations for industry were introduced in 1927 ("The act on industry law"). Crafts in Lublin in this period were ethnically strongly polarized between the two groups. Jews owned 60 percent of all the workshops in the city, while Poles held the rest of the crafts and services. Jewish craftsmen dominated mainly in textile (tailoring) and leather (shoemaking) industries and services like hairdressing or photography. The article focuses primarily on quantitative and statistic aspects of the discussed topic. Jewish craft organizations (craft guilds), supporting institutions (credit institutions for craftsmen) and Jewish personnel of the Lublin Chamber of Crafts are also presented.
\end{abstract}

Keywords: Lublin, Jews, crafts, handicraft, interwar period.

Słowa kluczowe: Lublin, Żydzi, rzemiosło, dwudziestolecie międzywojenne.

W schyłkowym okresie dwudziestolecia międzywojennego liczący 122 tys. mieszkańców Lublin był pod względem potencjału demograficznego jedenastym miastem w Rzeczypospolitej Polskiej ${ }^{1}$. Po Lwowie i Wilnie uznawano go wtedy za trzeci ośrodek miejski po prawej stronie Wisły i jako centrum przemysłowo-gospodarcze należał do średnich w skali kraju, a jego specyfiką było duże rozdrobnienie zakładów przemysłowych. $\mathrm{Na}$ terenie miasta istniało zaledwie kilka dużych fabryk zatrudniających

${ }^{1}$ Maty rocznik statystyczny 1939, R. 10, Warszawa 1939, s. 36. 
kilkuset pracowników, większość zaś lubelskich zakładów przemysłowych była niewielkimi lub średnimi podmiotami gospodarczymi, które dawały pracę od kilkunastu do kilkudziesięciu pracownikom. Ta sytuacja zaczęła się zmieniać w drugiej połowie lat trzydziestych w związku z budową Centralnego Okręgu Przemysłowego, który obejmował także województwo lubelskie. Zrealizowano wtedy kilka ważnych dla miasta inwestycji przemysłowych, np. fabrykę konserw Poels\&Co oraz halę montowni samochodów osobowych firmy Lilpop, Rau i Loewenstein ${ }^{2}$. Według danych zawartych w Roczniku politycznym i gospodarczym z roku 1939 w Lublinie działało 150 zakładów przemysłowych, które zatrudniały 8917 osób³.

Oblicze gospodarcze Lublina lat trzydziestych kształtowały przede wszystkim handel i rzemiosło, gdyż właśnie te rodzaje działalności zarobkowej dawały utrzymanie największej części mieszkańców. W 1936 r. funkcjonowały w Lublinie 3083 zakłady handlowe i działało 2588 zakładów rzemieślniczych ${ }^{4}$. Z pracy w rzemiośle utrzymywała się niemal jedna trzecia obywateli miasta - 32,6\% (podczas gdy przemysł dawał środki do życia zaledwie $8,1 \%$ populacji $)^{5}$. Handel i ubezpieczenia były źródłem dochodów dla $20 \%$ ludności miasta, z czego $60 \%$ czerpało je z handlu towarowego ${ }^{6}$.

Tym, co charakteryzowało lubelskie rzemiosło okresu międzywojennego, była wysoka pozycja Żydów, którzy w roku 1937 prowadzili 60\% wszystkich działających w mieście warsztatów (1733 wobec 1160 chrześcijańskich) ${ }^{7}$, przy czym w niektórych mieli wyraźną przewage, a często wręcz dominującą pozycję. Artykuł jest próbą odtworzenia obrazu tej właśnie części rzemieślniczego środowiska w Lublinie w latach trzydziestych XX w. Jest to jednocześnie pierwsze opracowanie przedstawiające szerzej temat rzemiosła żydowskiego w Lublinie w tym okresie, a więc po uchwaleniu i wejściu w życie nowych regulacji prawnych porządkujących także sprawy rzemiosła, czyli Rozporządzenia Prezydenta Rzeczypospolitej z dnia 7 czerwca 1927 r. o prawie przemysłowem. Uporządkowanie stanu prawnego rzemiosła przez wspomniany akt prawny i faktyczne rozpoczęcie pracy izb rzemieślniczych w 1929 r. zadecydowały o tym, że przyjąłem

\footnotetext{
2 Natalia Przesmycka, Lublin. Przeobrażenia urbanistyczne 1815-1939, Lublin 2012, s. 232.

${ }^{3}$ Rocznik polityczny i gospodarczy 1939, Warszawa 1939, s. 336.

${ }^{4}$ Historia Lublina w liczbach, Lublin 2018, s. 105.

${ }^{5}$ Stanisław Duda, Rozwój rzemiosta w Lublinie w okresie międzywojennym, „Annales UMCS", Sectio H, Oeconomia 25 (1991), nr 4, s. 53.

${ }^{6}$ Drugi powszechny spis ludności z dn. 9. XII 1931 r. Mieszkania i gospodarstwa domowe. Ludność. Stosunki zawodowe. Województwo lubelskie, Warszawa 1938, s. 277.

7 VIII Sprawozdanie Izby Rzemieślniczej w Lublinie za rok 1937, Lublin 1938, s. 78.
} 
określoną w tytule artykułu periodyzację, skupiając się na dekadzie lat trzydziestych. Nie bez znaczenia był też fakt znacznie większej niż dla lat dwudziestych ilości materiału statystycznego, co wiązało się przede wszystkim z działaniem izb, które miały ustawowy obowiązek prowadzenia statystyki rzemiosła.

\section{Materiał źródłowy}

Największym problemem, z jakim musi się mierzyć badacz rzemiosła żydowskiego w Lublinie w okresie międzywojennym, jest bardzo ograniczony zasób źródeł o charakterze statystycznym. Już w latach trzydziestych uwagę na ten brak zwracali autorzy corocznych sprawozdań publikowanych przez Izbę Rzemieślniczą w Lublinie, a także publicyści branżowej prasy rzemieślniczej zarówno regionalnej, jak i centralnej. Podkreślano, że Główny Urząd Statystyczny nie zajmuje się systematycznym badaniem najdrobniejszych placówek przemysłowych, szczególnie tych, które nie wykupywały świadectw przemysłowych lub wykupywały ostatnią, VIII kategorię przemysłową ${ }^{8}$. Tymczasem w rzemiośle lubelskim dominowały właśnie zakłady zatrudniające zwykle jednego lub dwóch pracowników, w tym właściciela. Większe, kilkunasto- lub kilkudziesięcioosobowe, należały do rzadkości. Ta tendencja była jeszcze bardziej powszechna w rzemiośle żydowskim, gdzie najliczniejsze były małe, rodzinne warsztaty, które rzadko zatrudniały pracowników najemnych, bardzo często natomiast opierały się na nigdzie nierejestrowanej pracy członków rodziny. Kryteria przyjęte przez GUS powodowały, że szczegółowych danych na temat najmniejszych zakładów przemysłowych, a wśród nich większość stanowiły warsztaty rzemieślnicze, próżno szukać w zestawieniach i wydawnictwach tej instytucji, np. rocznikach statystycznych, czy opublikowanych w „Statystyce Polski” wynikach spisu powszechnego z 1931 r. Spisy te są niejasne, gdyż nie wprowadzono w nich jednoznacznego podziału na przemysł i rzemiosło, lecz jedynie na kategorie, co nie zawsze określało charakter zakładu?

Publicyści prasy rzemieślniczej krytycznie odnosili się także do badań statystycznych prowadzonych przez jednostki podlegające Ministerstwu Pracy i Polityki Społecznej. Podmioty takie jak: urzędy instytucji

8 Tamże, s. 5. W tej kategorii mieściły się najmniejsze zakłady przemysłowe zatrudniające od jednego do czterech pracowników. Zob. Duda, Rozwój rzemiosta w Lublinie..., s. 47.

${ }_{9}^{9}$ Drugi powszechny spis..., s. 276-278. 
ubezpieczeń społecznych, Główny Urząd Ubezpieczeń, Kasy Chorych, Fundusz Bezrobocia czy Zakłady Ubezpieczeń od Wypadków, prowadziły co prawda własne badania oraz gromadziły i opracowywały dane, jednak z punktu widzenia statystyki rzemiosła były one bezużyteczne, gdyż podobnie jak w przypadku danych GUS nie wydzielano w nich działalności rzemieślniczej z szerszej kategorii, jaką był przemysł. Powoduje to, że uzyskanie danych dotyczących rzemiosła jako osobnej kategorii działalności przemysłowej (np. na temat częstości wypadków w rzemiośle lub jego obciążenia z tytułu podatków, ale także zatrudnienia i produkcji) jest praktycznie niemożliwe ${ }^{10}$.

Biorąc pod uwagę powyższe spostrzeżenia na temat fragmentaryczności i niedoskonałości danych publikowanych przez wspomniane instytucje centralne, należy podkreślić, że podstawowym źródłem wiedzy na temat stanu lubelskiego rzemiosła żydowskiego, zwłaszcza w ujęciu ilościowym, pozostają sprawozdania Izby Rzemieślniczej w Lublinie. Jednak i to źródło nie jest wolne od wad. Wynika to przede wszystkim z faktu, że przygotowujący raporty pracownicy Izby opierali się głównie na informacjach przekazywanych przez organizacje rzemieślnicze (np. cechy), które nie zawsze wywiązywały się ze swoich obowiązków sprawozdawczych, a ponadto swym zasięgiem nie obejmowały całego środowiska rzemieślniczego.

Dane dotyczące liczebności legalnie działających zakładów rzemieślniczych opierały się na prowadzonych przez władze przemysłowe pierwszej instancji (starostwa powiatowe) rejestrach, którym także zarzucano, że zawarte w nich informacje nie odpowiadają stanowi faktycznemu ${ }^{11}$. Także dane na temat zatrudnienia czy podziału pracowników na mistrzów, czeladników i terminatorów podawano jedynie w przybliżeniu ${ }^{12}$.

Realizując nałożone na nią obowiązki statystyczne ${ }^{13}$, Izba Rzemieślnicza opierała swoje ustalenia także na badaniach ankietowych wśród rzemieślników. Była to jednak metoda pracochłonna i kosztowna, a przede wszystkim obarczona dużym marginesem błędu. W prasie branżowej zwracano uwagę na to, że arkusze ankietowe są sporządzane przez izby z dużą dozą dowolności, jeśli chodzi o treść, przez co znacznie różnią się od siebie i nie są pełne. Podkreślano także, że szerzej zakrojone badania statystyczne

${ }^{10}$ Kazimierz Jaroszewski, Statystyka w rzemiośle, „Rzemiosło” 1 (lipiec-wrzesień 1932), z. 3-5, s. 100-101.

${ }^{11}$ V Sprawozdanie Izby Rzemieślniczej w Lublinie za rok 1934, Lublin 1935, s. 27.

${ }_{12}$ II Sprawozdanie Izby Rzemieślniczej w Lublinie za rok 1931, Lublin 1932, s. 12.

${ }^{13}$ Rozporządzenie Prezydenta Rzeczypospolitej z dnia 27 października 1933 r. o izbach rzemieślniczych i ich związku, Dz.U. 1933, nr 85, poz. 638. 
były prowadzone tylko przez niektóre izby, co jest następną przyczyną fragmentaryczności materiału statystycznego dotyczącego rzemiosła ${ }^{14}$.

W przypadku badań ankietowych zwracano uwagę na niski poziom wykształcenia osób zatrudnionych w rzemiośle (przede wszystkim duży odsetek analfabetów, zwłaszcza wśród ludności żydowskiej), co bardzo utrudniało, a często wręcz uniemożliwiało prowadzenie badań korespondencyjnych (ankietowanie bezpośrednie było niemożliwe ze względu na brak wystarczającej liczby pracowników izb). Innym problemem było także częste podawanie przez ankietowanych nieprawdziwych (zaniżonych) danych, przede wszystkim dotyczących zatrudnienia, co wiązało się m.in. z chęcią uniknięcia obowiązków prawno-podatkowych nakładanych na zakłady zatrudniające większą liczbę pracowników.

Istotnym mankamentem materiału statystycznego, jakiego dostarczają sprawozdania Izby Rzemieślniczej w Lublinie, jest również to, że tylko częściowo przedstawia on dane z podziałem na chrześcijan i Żydów. A jeśli nawet ten podział został uwzględniony, należy jednak podchodzić doń z pewną dozą krytycyzmu, bo - jak przyznawali autorzy sprawozdań opierano go przede wszystkim na brzmieniu nazwiska ${ }^{15}$. W podobnym tonie wypowiadał się autor jedynej przedwojennej monografii poświęconej rzemiosłu żydowskiemu w Polsce - Izaak Bornstein, który podkreślając brak wyodrębnienia rzemiosła z ogółu działalności przemysłowej, zwracał też uwagę na to, że izby rzemieślnicze w swoich sprawozdaniach sporadycznie uwzględniały podział wyznaniowy ${ }^{16}$.

Materiał dostarczany przez Izbę Rzemieślniczą w Lublinie cechuje duży stopień chaotyczności oraz brak jednolitych kryteriów wyboru i prezentacji danych. W niektórych sprawozdaniach podawane są one szczegółowo, z uwzględnieniem podziału na chrześcijan i Żydów (np. za lata 1933 i 1937), w innych zaś w sposób uproszczony i niepełny. Taki stan materiału statystycznego powoduje, że przy badaniu niektórych aspektów ilościowych rzemiosła żydowskiego w Lublinie trzeba opierać się na szacunkach, wykorzystując wszelkie dostępne w źródłach i opracowaniach naukowych dane statystyczne z zakresu opisywanej w tym artykule tematyki.

Wartościowe informacje na temat rzemiosła znajdują się także w Archiwum Państwowym w Lublinie, w zespołach: Akta Miasta Lublina (Oddział Rachuby, Wydział Administracyjny), Urząd Wojewódzki Lubelski (Wydział

${ }^{14}$ Jaroszewski, Statystyka w rzemiośle..., s. 100.

${ }_{15}$ IV Sprawozdanie Izby Rzemieślniczej w Lublinie za rok 1933, Lublin 1934, s. 39.

${ }^{16}$ Izaak Bornstein, Rzemiosto żydowskie w Polsce, Warszawa 1936, s. 44. 
Przemysłowy), Starostwo Powiatowe Lubelskie i Starostwo Grodzkie Lubelskie (jednostki dotyczące stowarzyszeń, kas bezprocentowych, a także sprawozdania starosty grodzkiego, w których znaleźć można dane dotyczące działalności ruchu zawodowego w mieście). Informacje na temat zakładów rzemieślniczych prowadzonych przez Żydów można znaleźć także w archiwum zakładowym Lubelskiej Izby Rzemiosła i Przedsiębiorczości, gdzie przechowywane są takie dokumenty, jak ewidencja mistrzów czy uprawnienia dotyczące szkolenia uczniów, które obejmują swoim zakresem także okres międzywojenny. Cennej wiedzy dostarczają również nieliczne zachowane źródła w języku żydowskim, takie jak Dos bukh fun Lublin... [Księga Lublina: wspomnienia, relacje i materiały o życiu, walce i męczeństwie żydowskiej społeczności Lublina $]^{17}$ czy lubelska prasa żydowska dziennik „Lubliner Tugblat” i tygodnik „Lubliner Sztyme”.

\section{Społeczność żydowska Lublina}

W okresie dwudziestolecia międzywojennego Żydzi stanowili około jedną trzecią populacji Lublina. Według danych ze spisu powszechnego z $1931 \mathrm{r}$. 38937 osób wśród 112285 mieszkańców miasta, czyli 34,67\%, to mniejszość żydowska ${ }^{18}$. W późniejszych latach odsetek ten nieco się zmniejszył i tuż przed wybuchem II wojny światowej Żydzi stanowili w Lublinie 32,5\% mieszkańców. Wśród wojewódzkich miast ówczesnej Polski wyższy procent ludności żydowskiej zamieszkiwał tylko we Lwowie $(37,9 \%)^{19}$.

Tym, co charakteryzowało społeczność żydowską międzywojennego Lublina, był niski stopień asymilacji, jeden z najniższych spośród największych miast Polski. Tylko 2,5\% żydowskich mieszkańców miasta deklarowało język polski jako ojczysty, podczas gdy w Warszawie było to 5,5\%, w Krakowie - 18,6\%, we Lwowie - 24,1\%, a w Poznaniu -29,2\%. Świadczy to zarówno o wolniejszych w Lublinie niż w innych dużych ośrodkach miejskich procesach asymilacji, jak również o większej izolacji kulturowej lubelskich Żydów i słabszych relacjach z chrześcijańskim otoczeniem ${ }^{20}$.

${ }^{17}$ Dos bukh fun Lublin: zikhrojnes, gvies-eydes un materyaln ibernlebn, kamf un martirertum fun lubliner Yidiszn yiszew, Pariz 1952.

${ }_{18}$ Drugi powszechny spis..., s. 31.

19 Tadeusz Radzik, Społeczność żydowska Lublina w międzywojennym dwudziestoleciu. Obraz statystyczny, [w:] Żydzi w Lublinie, t. 1: Materiaty do dziejów społeczności żydowskiej Lublina, red. Tadeusz Radzik, Lublin 1995, s. 146.

${ }^{20}$ Tadeusz Radzik, Żyli z nami, [w:] Lublin $w$ dziejach $i$ kulturze Polski, red. Tadeusz Radzik, Adam A. Witusik, Lublin 1997, s. 267. 
Żydowska społeczność Lublina była bardzo słabo wykształcona. Cechował ją wyjątkowo wysoki - jak na tę grupę etniczną - odsetek analfabetów. W 1921 r. stanowili oni aż 42,5\%, co znacznie odbiegało od wskaźnika ogólnopolskiego dla ludności żydowskiej, który wynosił $28,3 \%$, a dla mieszkańców miast - 25,1\%. W tym czasie wśród chrześcijan w Lublinie było $26,9 \%$ analfabetów ${ }^{21}$. Oczywiście poziom alfabetyzacji dotyczy urzędowego w II RP języka polskiego. Wewnątrz własnej społeczności Żydzi posługiwali się przede wszystkim jidysz (w życiu codziennym) i hebrajskim (język liturgii), co oczywiście nie znaczy, że wszyscy umieli płynnie czytać i pisać w tym pierwszym języku, nie mówiąc już o hebrajskim, który na tym poziomie był znany przez mały odsetek ludności żydowskiej.

W strukturze zawodowej lubelskiego żydostwa oprócz rzemiosła dominował drobny handel i usługi. Były to w zdecydowanej większości małe zakłady zatrudniające jednego lub dwóch pracowników, bardzo często członków rodziny właściciela. Znalezienie zatrudnienia poza środowiskiem żydowskim nie było łatwe. Spowodowane to było m.in. koniecznością powstrzymywania się od pracy przez dwa dni w tygodniu (w sobotę, która była religijnym świętem żydowskim, i w niedzielę, ustawowo wolną od pracy i handlu). $\mathrm{Z}$ tego powodu żydowscy robotnicy najemni pracowali głównie u innych Żydów, a liczba zatrudnionych w zakładach chrześcijańskich była niewielka ${ }^{22}$.

Także z punktu widzenia topograficznego rozmieszczenia społeczności żydowskiej międzywojennego Lublina mówić można o izolacji. Zamieszkiwała ona miasto w zwartych skupiskach, głównie w śródmieściu, gdzie według pierwszego spisu ludności z 1921 r. Żydzi stanowili ponad połowę populacji $(52,07 \% \text {, podczas gdy na przedmieściach mieszkało } 20,8 \%)^{23}$. Wymienić należy przede wszystkim tzw. dzielnicę żydowską usytuowaną wokół lubelskiego zamku, w części Starego Miasta oraz w okolicach ul. Lubartowskiej będącej - wraz z ul. Szeroką - centrum życia społecznego, ekonomicznego i kulturalnego tego obszaru. Badająca tę problematykę Natalia Przesmycka pisała:

To tam skupiał się drobny handel i rzemiosło zlokalizowane przeważnie w parterach kamienic, dostępnych od ulicy, a także w mieszkaniach i we wszelkich możliwych pomieszczeniach adaptowanych na zakłady czy sklepiki. [...] Głównym placem handlowym, zwanym Targiem Rybnym, było trójkątne targowisko z kramami

${ }^{21}$ Tamże.

${ }^{22}$ Tamże.

${ }^{23}$ Archiwum Państwowe w Lublinie [dalej: APL], Akta Miasta Lublina, Oddział Rachuby, sygn. 1074 . 
i jatkami, przylegające do ulicy Lubartowskiej i Czechówki. Handlowano również na placykach u zbiegu ulic Szerokiej, Podzamcza, Kowalskiej i Cyruliczej oraz na ulicach $^{24}$.

W dzielnicy żydowskiej panowały trudne warunki mieszkaniowe i sanitarne. O ile przy reprezentacyjnej ulicy, jaką była Lubartowska, stan budynków był zwykle dobry ${ }^{25}$, o tyle w miarę oddalania się od niej warunki bytowe były coraz gorsze. Najbiedniejszą i najbardziej zaniedbaną część żydowskiego miasta stanowiły tereny położone na wschód i południe od wzgórza zamkowego (ul. Krawiecka i Podzamcze) oraz przylegające do rzeki Czechówki, gdzie dominowała niska, przede wszystkim drewniana zabudowa. Rzeka była jedną z głównych przyczyn problemów sanitarnych tej części miasta, gdyż spływały do niej ścieki i nieczystości z położonych wyżej domów, kamienic, a także zakładów przemysłowych ${ }^{26}$.

Oprócz wymienionych tu terenów Żydzi zamieszkiwali również inne części Lublina, w tym jego dawne przedmieścia, które w okresie międzywojennym i wcześniej znalazły się w granicach administracyjnych miasta. W zwartym skupisku społeczność ta mieszkała w Wieniawie, która do 1916 r. pozostawała oddzielnym miasteczkiem. Dominowała tu drewniana architektura, mieszkańcy żyli w nadzwyczaj prymitywnych warunkach, a uboga ludność tej dzielnicy była źródłem taniej siły roboczej dla miasta ${ }^{27}$. Żydzi lubelscy mieszkali także na Czwartku, Kalinowszczyźnie oraz na przedmieściu Piaski, w okolicach dworca kolejowego. Niewielka grupa zasymilowanych i bardziej zamożnych Żydów, w tym bogatych rzemieślników, zamieszkiwała ścisłe centrum miasta, czyli Krakowskie Przedmieście i sąsiadujące z nim ulice.

\section{Stan rzemiosła żydowskiego}

Analizując dostępne dane na temat liczebności żydowskich zakładów w Lublinie w latach trzydziestych, można zauważyć wyraźną tendencję wzrostową. W 1933 r. w mieście działało 1339 samoistnych żydowskich warsztatów ${ }^{28}$, w 1935 r. było ich już $1552^{29}$. W 1937 r. liczba ta wzrosła do

${ }^{24}$ Przesmycka, Lublin..., s. 215.

25 Tamże, s. 217.

26 Tamże, s. 216.

27 Tamże, s. 146-147.

${ }^{28}$ IV Sprawozdanie Izby Rzemieślniczej w Lublinie..., tablica $\mathrm{nr} 1$.

${ }^{29}$ Cecylian Ptasiński, Studium o rozmiarach, strukturze, wytwórczości i rozmieszczeniu rzemiost w województwie lubelskim, Lublin 1939, s. V. 
1733 przedsiębiorstw, co stanowiło $60 \%$ wszystkich zakładów rzemieślniczych działających w Lublinie ${ }^{30}$. Wzrost liczebności zakładów nie oznaczał jednak przyrostu zatrudnienia. To bowiem spadało, o czym świadczy liczba świadectw przemysłowych wykupywanych przez zakłady: w 1930 r. było ich 5171, rok później zaś już tylko 2956. Ponieważ przepisy podatkowe wymagały wykupienia świadectwa przemysłowego VIII kategorii przez przedsiębiorstwa zatrudniające od dwóch do czterech pracowników, oznacza to, że właściciele 2215 zakładów ograniczyli zatrudnienie do jednego pracownika. Częste były też sytuacje, w których za warsztatem stawał jedynie sam właściciel ${ }^{31}$. Zwalniani z zakładów pracownicy albo powiększali grono bezrobotnych, albo zakładali własne, najczęściej nielegalne punkty produkcji. Tylko przez dwa lata pomiędzy rokiem 1935 a 1937 liczba warsztatów bez wymaganej przepisami prawa karty rzemieślniczej ${ }^{32}$ wzrosła z 72 do 210 , czyli niemal trzykrotnie.

Spośród wszystkich zawodów rzemieślniczych, jakie wykonywano na terenie Lublina, można wyróżnić grupę, w której rzemieślnicy Żydzi i prowadzone przez nich zakłady stanowiły większość. Wiedli oni prym przede wszystkim w rzemiosłach należących do przemysłu odzieżowego i galanteryjnego, co było zresztą tendencją ogólnopolską ${ }^{33}$.

Stan liczebny zakładów, w których większość stanowili rzemieślnicy Żydzi, obrazuje tabela 1. Dla porównania uwzględniono w niej również liczebność przedsiębiorstw chrześcijańskich. Z przedstawionych tam danych wynika, że w niektórych zawodach (np. w przypadku szewstwa i cukiernictwa) wraz z upływem lat stan liczebny zmieniał się na korzyść rzemiosła żydowskiego.

Ze względu na brak jednoznacznych informacji stan zatrudnienia w rzemiośle żydowskim w Lublinie lat trzydziestych jest bardzo trudny do ustalenia. $\mathrm{Z}$ tego względu podane niżej liczby mają charakter wyłącznie szacunkowy. Przyjmując za Aleksandrem Kierkiem, że w 1936 r. w rzemiośle

${ }^{30}$ VIII Sprawozdanie Izby Rzemieślniczej w Lublinie..., s. 78.

${ }^{31}$ II Sprawozdanie Izby Rzemieślniczej w Lublinie..., s. 3.

${ }^{32}$ Karta rzemieślnicza była podstawą do prowadzenia legalnej działalności rzemieślniczej. Wydawało ją - jako właściwy organ władzy przemysłowej - Starostwo Powiatowe na podstawie tzw. dowodu uzdolnienia zawodowego. Zob.: art. 147 Rozporządzenia Prezydenta Rzeczypospolitej z dnia 7 czerwca 1927 r. o prawie przemysłowem, Dz.U. 1927, nr 53, poz. 468.

${ }_{33}$ W skali kraju Żydzi stanowili blisko połowę $(46,9 \%)$ w tej gałęzi przemysłu. Zob.: Jerzy Gliksman, Struktura zawodowa i społeczna ludności żydowskiej w Polsce, Warszawa 1930, s. 14. 
Tabela 1. Liczebność zakładów rzemieślniczych (łącznie legalnych i nielegalnych), które w większości należały do Żydów (Ż.), w porównaniu z liczebnością odpowiednich przedsiębiorstw chrześcijańskich (Ch.) w roku 1933 i 1937

\begin{tabular}{|c|c|c|c|c|c|c|c|c|c|c|c|}
\hline \multirow{4}{*}{ Lp. } & \multirow{4}{*}{ Zawód } & \multicolumn{10}{|c|}{ Liczebność zakładów rzemieślniczych w roku 1933 i 1937} \\
\hline & & \multicolumn{5}{|c|}{1933} & \multicolumn{5}{|c|}{1937} \\
\hline & & \multicolumn{2}{|c|}{$\dot{\mathbf{Z}}$. } & \multicolumn{2}{|c|}{ Ch. } & \multirow{2}{*}{ 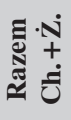 } & \multicolumn{2}{|c|}{$\dot{\mathbf{Z}}$. } & \multicolumn{2}{|c|}{ Ch. } & \multirow{2}{*}{ 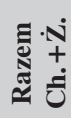 } \\
\hline & & liczba & $\%$ & liczba & $\%$ & & liczba & $\%$ & liczba & $\%$ & \\
\hline 1 & Krawiectwo & 359 & 82,7 & 75 & 17,3 & 434 & 345 & 80 & 86 & 20 & 431 \\
\hline 2 & Szewstwo & 132 & 44,4 & 165 & 55,6 & 297 & 317 & 56,9 & 240 & 43,1 & 557 \\
\hline 3 & Stolarstwo & 103 & 66 & 53 & 34 & 156 & 132 & 57,9 & 96 & 42,1 & 228 \\
\hline 4 & Rzeźnictwo & 70 & 66 & 36 & 34 & 106 & 108 & 66,3 & 55 & 33,7 & 163 \\
\hline 5 & Fryzjerstwo & 70 & 60,9 & 45 & 39,1 & 115 & 107 & 62,6 & 64 & 37,4 & 171 \\
\hline 6 & Piekarstwo & 89 & 74,8 & 30 & 25,2 & 119 & 93 & 65,5 & 49 & 34,5 & 142 \\
\hline 7 & Cholewkarstwo & 58 & 92 & 5 & 8 & 63 & 84 & 93,3 & 6 & 6,7 & 90 \\
\hline 8 & Malarstwo & 72 & 78,3 & 20 & 21,7 & 92 & 78 & 65 & 42 & 35 & 120 \\
\hline 9 & Blacharstwo & 52 & 75,4 & 17 & 24,6 & 69 & 68 & 76,4 & 21 & 23,6 & 89 \\
\hline 10 & Zegarmistrzostwo & 46 & 93,9 & 3 & 6,1 & 49 & 51 & 89,5 & 6 & 10,5 & 57 \\
\hline 11 & Kuśnierstwo & 54 & 94,7 & 3 & 5,3 & 57 & 48 & 96 & 2 & 4 & 50 \\
\hline 12 & Szklarstwo & 25 & 96,1 & 1 & 3,9 & 26 & 28 & 93,3 & 2 & 6,7 & 30 \\
\hline 13 & Rymarstwo & 25 & 92,6 & 2 & 7,4 & 27 & 27 & 73 & 10 & 27 & 37 \\
\hline 14 & Fotografia & 17 & 65,4 & 9 & 34,6 & 26 & 27 & 71 & 11 & 29 & 38 \\
\hline 15 & Czapnictwo & 26 & 96,3 & 1 & 3,7 & 27 & 22 & 84,6 & 4 & 15,4 & 26 \\
\hline 16 & Jubilerstwo & 19 & 90,5 & 2 & 9,5 & 21 & 21 & 87,5 & 3 & 12,5 & 24 \\
\hline 17 & Cukiernictwo & 6 & 30 & 14 & 70 & 20 & 21 & 51,2 & 20 & 48,8 & 41 \\
\hline 18 & Brązownictwo & 8 & 100 & - & - & 8 & 12 & 100 & - & - & 12 \\
\hline 19 & Introligatorstwo & 11 & 78,6 & 3 & 2,4 & 14 & 12 & 52,2 & 11 & 47,8 & 23 \\
\hline 20 & Wyrób szkieł & 2 & 100 & - & - & 2 & 8 & 100 & - & - & 8 \\
\hline 21 & Szczotkarstwo & 14 & 87,5 & 2 & 12,5 & 16 & 8 & 80 & 2 & 20 & 10 \\
\hline 22 & Kapelusznictwo & 37 & 80,4 & 9 & 19,6 & 46 & 7 & 50 & 7 & 50 & 14 \\
\hline 23 & Tapicerstwo & 13 & 72,2 & 5 & 27,8 & 18 & 7 & 50 & 7 & 50 & 14 \\
\hline 24 & Bieliźniarstwo & - & - & - & - & - & 6 & 100 & - & - & 6 \\
\hline 25 & Tokarstwo drzewa & 4 & 100 & - & - & 4 & 5 & 83,3 & 1 & 16,7 & 6 \\
\hline 26 & Farbiarstwo & - & - & - & - & - & 5 & 83,3 & 1 & 16,7 & 6 \\
\hline 27 & Grawerstwo & 7 & 87,5 & 1 & 12,5 & 8 & 5 & 62,5 & 3 & 37,5 & 8 \\
\hline 28 & Gorseciarstwo & - & - & - & - & - & 2 & 66,7 & 1 & 33,3 & 3 \\
\hline 29 & Rękawiczkarstwo & 1 & 50 & 1 & 50 & 2 & 2 & 66,7 & 1 & 33,3 & 3 \\
\hline
\end{tabular}

Źródło: opracowanie własne na podstawie sprawozdań Izby Rzemieślniczej w Lublinie z lat 1933 i 1937. 
pracowało w Lublinie łącznie około 6500 osób ${ }^{34}$, a udział rzemiosła żydowskiego w 1937 r. wynosił 60\% ${ }^{35}$, stan zatrudnienia w żydowskich zakładach rzemieślniczych należy oszacować na około 3900 osób.

Można też przyjąć inny szacunek. Sprawozdanie Izby Rzemieślniczej w Lublinie za rok 1937 podaje, że na terenie miasta działały 1733 żydowskie zakłady (1523 legalne i 210 nielegalnych). Jeśli uwzględnimy wskaźnik zatrudnienia w zakładzie rzemieślniczym w Lublinie, który w tym okresie wynosił 125 osób na 100 zakładów (nie licząc właściciela) ${ }^{36}$, przemnożymy przezeń powyższą liczbę zakładów i dodamy grupę samoistnych właścicieli, to uzyskujemy niemal identyczny wynik: 3899 osób ${ }^{37}$.

Jest to jednak dolna granica zatrudnienia w rzemiośle żydowskim, gdyż dane statystyczne publikowane przez lubelską Izbę nie uwzględniały chałupników. Z prawnego punktu widzenia nie byli oni bowiem samoistnymi rzemieślnikami prowadzącymi własne przedsiębiorstwa, choć przecież wykonywali zawody rzemieślnicze i w znacznej mierze rekrutowali się z bezrobotnych, dla których w latach kryzysu zabrakło zatrudnienia w samoistnych warsztatach ${ }^{38}$.

Porównując uzyskany wynik z liczbą ludności żydowskiej Lublina według spisu powszechnego z 1931 r., która wynosiła 38937 osób, widać, że co najmniej $10 \%$ całej żydowskiej populacji miasta trudniło się rzemiosłem. Ze względu na brak danych na temat odsetka czynnej zawodowo ludności żydowskiej Lublina nie można ustalić, jaki był procent aktywnych zawodowo Żydów pracujących w tej gałęzi przemysłu ${ }^{39}$. Ogólna liczba ludności czynnej zawodowo wynosiła w tym czasie w Lublinie 44940 osób ${ }^{40}$. Żydowscy rzemieślnicy stanowili więc 8,7\% ogółu czynnych zawodowo w Lublinie, zarówno Żydów, jak i chrześcijan.

${ }^{34}$ Aleksander Kierek, Rozwój gospodarczy Lublina w latach 1918-1939, [w:] Dzieje Lublina, t. 2, red. Stanisław Krzykała, Lublin 1975, s. 68.

35 VIII Sprawozdanie Izby Rzemieślniczej w Lublinie..., s. 78.

36 Tamże, s. 88.

${ }^{37}$ Liczba zakładów pomnożona przez współczynnik zatrudnienia (co daje liczbę pracowników najemnych), powiększona o liczbę właścicieli: $(1733 \times 1,25)+1733=2166,25+1733$ $=3899$.

${ }^{38}$ Dane na temat zatrudnionych w rzemiośle lubelskim Żydów podają także Karolina Wajs i Symcha Wajs - zob. Karolina Wajs, Symcha Wajs, Fakty $i$ wydarzenia z życia lubelskich Żydów, Lublin 1997, s. 61. Autorzy powołują się na bliżej niesprecyzowane dane z 25 października 1939 r., według których w Lublinie w tym czasie było 4739 rzemieślników żydowskich.

${ }^{39} \mathrm{~W}$ skali kraju odsetek ludności żydowskiej czynnej zawodowo wynosił w tym czasie ok. 34\%. Zob.: Gliksman, Struktura zawodowa i społeczna..., s. 5.

${ }^{40}$ Drugi powszechny spis..., s. 276. 
O ile ustalenie, jaka liczba lubelskich Żydów bezpośrednio (jako samoistni właściciele i pracownicy najemni) zajmowała się rzemiosłem, jest stosunkowo proste, o tyle o wiele trudniej jest oszacować, jak liczna była populacja, dla której rzemiosło było podstawowym źródłem utrzymania. Według danych ujętych w sprawozdaniu Izby Rzemieślniczej w Lublinie za 1932 r. na utrzymaniu jednego samoistnego zakładu rzemieślniczego pozostawało przeciętnie pięć osób z rodziny właściciela ${ }^{41}$. Można zatem przyjąć, że 1733 zakłady utrzymywały 8665 osób, które należały do rodziny właściciela. Do tej liczby należy dodać zatrudnionych w zakładach pracowników najemnych, czyli około 2166 osób. Daje to wynik 10831 osób, co stanowiło 27,8\% żydowskiej populacji Lublina. Jest to jednak w dalszym ciągu liczba zaniżona, gdyż ze względu na brak danych w szacunkach nie uwzględniono członków rodzin będących na utrzymaniu zatrudnionych w warsztatach pracowników najemnych.

Mimo liczebnej przewagi zakłady żydowskie, nastawione na zaspokajanie potrzeb uboższej klienteli, cechował zazwyczaj niższy poziom organizacyjny i techniczny od tego, jaki miały warsztaty chrześcijańskie. Były one przede wszystkim o wiele gorzej wyposażone w maszyny i urządzenia ${ }^{42}$, co odbijało się na jakości produkcji i świadczonych usług, szczególnie w zawodach, w których dominowali chrześcijanie. Warunki prowadzenia działalności rzemieślniczej przez Żydów również były gorsze niż u chrześcijan. Do rzadkości należały przedsiębiorstwa dysponujące lokalami przeznaczonymi wyłącznie na cele produkcji lub usług. Warsztat rzemieślnika Żyda najczęściej mieścił się w pomieszczeniu, które prócz miejsca pracy pełniło jednocześnie funkcje mieszkalne dla rzemieślnika i jego rodziny ${ }^{43}$.

\section{Żydowskie cechy w Lublinie}

Środowisko rzemieślnicze Lublina, zarówno chrześcijańskie, jak i żydowskie, było reprezentowane przez dwa rodzaje organizacji. Tradycyjną formą samorządu rzemieślniczego, której historia sięgała czasów średniowiecza, były cechy. Ich organizację oraz uprawnienia regulowało Rozporządzenie Prezydenta Rzeczypospolitej z dnia 7 czerwca 1927 r. o prawie

${ }^{41}$ III Sprawozdanie Izby Rzemieślniczej w Lublinie za rok 1932, Lublin 1933, s. 50.

${ }^{42}$ Według Izaaka Bornsteina nawet trzy czwarte wszystkich żydowskich zakładów w Polsce pozostawało bez maszyn. Zob.: Bornstein, Rzemiosło żydowskie w Polsce..., s. 73.

${ }^{43}$ Izaak Bornstein podaje, że nawet $75 \%$ wszystkich żydowskich warsztatów rzemieślniczych mieściło się w lokalach mieszkalnych. Tamże, s. 72. 
przemysłowem oraz jego późniejsze nowelizacje z lat trzydziestych. Drugą formą zrzeszania się rzemieślników były stowarzyszenia, których działalność regulowała ustawa zwykła o stowarzyszeniach.

Do roku 1927 w rzemiośle lubelskim dominowały cechy chrześcijańskie ${ }^{44}$. Przełomem było wspomniane wyżej rozporządzenie o prawie przemysłowym. Po wejściu w życie nowych przepisów nastąpił gwałtowny rozwój tego rodzaju zrzeszeń wśród żydowskich rzemieślników z Lublina i Lubelszczyzny. W latach 1928-1930 na 97 cechów powstałych na terenie całego województwa aż 81 (83\%) założyli Żydzi. W późniejszym okresie ta dynamika była już mniejsza, ale jeszcze w roku 1931 żydowskie organizacje stanowiły $40 \%$ nowo powstających cechów $(20 \text { z } 49)^{45}$. Zawiązywały się też nieliczne zrzeszenia mieszane. Były to na ogół organizacje chrześcijańskie, do których przyjmowano rzemieślników żydowskich, tworzących w nich jednak zdecydowaną mniejszość. Nie odnotowałem natomiast ani jednego cechu żydowskiego, do którego zgłaszaliby akces chrześcijanie.

Mimo dynamicznego rozwoju cechów żydowskich w końcu lat dwudziestych następną dekadę charakteryzuje stopniowa marginalizacja tych organizacji, co było zjawiskiem charakterystycznym dla całego rzemiosła II RP:

Działalność cechów uległa [...] dalszemu ograniczeniu, co tłumaczy się [...] ogólnym zubożeniem, brakiem funduszów, brakiem lokali, odpowiedniego personelu biurowego, niedostatecznym wyrobieniem zmysłu organizacyjnego, [...] a nade wszystko powszechnym mniemaniem, że cechy nie posiadają dostatecznie szerokich uprawnień ${ }^{46}$.

Postępująca w latach trzydziestych degradacja pozycji cechów wynikała z odebrania im - na rzecz izb rzemieślniczych - większości kompetencji, takich jak prawo rejestrowania umów o naukę czy przeprowadzania egzaminów czeladniczych i mistrzowskich, a także wyłączenia z dziedziny gospodarczej i uzależnienia finansów cechów tylko od dobrowolnych składek członkowskich. Można powiedzieć, że cechy w ten sposób pozbawiono wszelkich atrybutów władzy. Rzemieślnik mógł się bez nich obejść, a sprawy administracyjne załatwić w Izbie Rzemieślniczej ${ }^{47}$. Poza tym cechy nie troszczyły się o rozwój produkcji, ograniczając swoją działalność do zwalczania rzemieślników niezrzeszonych w cechach oraz szkolenia

${ }^{44}$ II Sprawozdanie Izby Rzemieślniczej w Lublinie..., s. 19.

${ }^{45}$ Tamże.

46 Cecylian Ptasiński, Rzemiosto w Polsce wspótczesnej, Lublin 1934, s. 189.

${ }^{47}$ VI Sprawozdanie Izby Rzemieślniczej w Lublinie za rok 1935, Lublin 1936, s. 103. 
uczniów ${ }^{48}$. Równie krytycznie o działalności tych organizacji pisano w sprawozdaniach rocznych wydawanych przez Izbę Rzemieślniczą w Lublinie:

Cechy nie wykazały się niemal żadnym dorobkiem. [...] Poza nielicznymi wyjątkami stanowią [...] organizacje bardzo słabe pod względem liczebności członków oraz środków finansowych, których przeważnie nie wystarcza na zaspokojenie najpotrzebniejszych potrzeb kancelaryjnych ${ }^{49}$.

Krytyka ta znajduje potwierdzenie w dokumentach sporządzonych po lustracji cechów lubelskich w 1935 r. W większości przypadków urzędnicy zwracali uwagę na nikłą aktywność tych organizacji (niewielka liczba zebrań, a często nawet brak jakichkolwiek posiedzeń) oraz problemy z płatnością składek będących podstawowym źródłem utrzymania organizacji ${ }^{50}$. Ten impas dotykał szczególnie boleśnie cechy żydowskie, które stale borykały się z niedostatkiem środków finansowych. Nie posiadały wystarczających kapitałów, nie dysponowały własnymi nieruchomościami, a ich oszczędności były zazwyczaj bardzo skromne, dlatego też nie mogły sprawnie działać na rzecz swoich członków - na przykład poprzez powoływanie dla nich kas zaliczkowych udzielających rzemieślnikom bezprocentowego, a nawet bezzwrotnego wsparcia finansowego, co było częste w organizacjach chrześcijańskich ${ }^{51}$.

Nic dziwnego, że w środowisku żydowskich rzemieślników w Lublinie entuzjazm wobec tej formy zrzeszania się z roku na rok malał. Wyraźnie widać to po spadającej liczbie organizacji rzemieślniczych w mieście, a także po odpływie ich członków. Według sprawozdania Izby Rzemieślniczej za lata 1929-1930 na początku dekady działało w Lublinie 19 wyłącznie żydowskich cechów (oraz jeden mieszany), które zrzeszały 626 członków ${ }^{52}$. Rok później było w nich już 777 rzemieślników narodowości żydowskiej. Ostatni, opublikowany przez Izbę w roku 1937 raport podaje, że na terenie miasta funkcjonowało już tylko 9 żydowskich organizacji cechowych, do których należało 474 rzemieślników.

Wyraźny spadek liczby cechów był także wynikiem wejścia w życie Rozporządzenia Ministra Przemysłu i Handlu z dnia 20 lutego 1936 r.

48 Duda, Rozwój rzemiosła w Lublinie..., s. 47.

${ }^{49}$ IV Sprawozdanie Izby Rzemieślniczej w Lublinie..., s. 41.

50 APL, Urząd Wojewódzki Lubelski [dalej: UWL], Wydział Przemysłowy [dalej: WP], sygn. 835 .

${ }^{51}$ II Sprawozdanie Izby Rzemieślniczej w Lublinie..., s. 83.

52 Sprawozdanie Izby Rzemieślniczej w Lublinie: 1) Ze stanu rzemiosta w 1930 r. 2) Z dziatalności za lata: 1929 i 1930, Lublin 1931, s. 26-27. 
o cechach rzemieślniczych (Dz.U. 1936, nr 16, poz. 147), które zmieniało przepisy dotyczące organizacji i działania cechów. Jednym z wymogów dopuszczenia cechu do dalszego działania było przedłożenie władzom przemysłowym w terminie do 3 września 1936 r. statutu sporządzonego według zawartego w rozporządzeniu wzoru; statut dodatkowo musiał być pozytywnie zaopiniowany przez właściwą izbę rzemieślnicząa ${ }^{53}$. Cechy, które tego wymogu nie spełniły, zakończyły tym samym działalność.

Szczegółowe dane na temat liczebności cechów w Lublinie w latach trzydziestych pokazuje tabela 2, w tabeli 3 natomiast uwzględniono osoby, które w latach 1930-1937 pełniły funkcje starszych cechów ${ }^{54}$.

Cechy obejmowały swoją działalnością niewielką liczebnie część środowiska żydowskich rzemieślników. Przyjmując ustalone wyżej szacunki dotyczące zatrudnienia w rzemiośle żydowskim w Lublinie w latach 1936-1937, możemy stwierdzić, że do cechów należało zaledwie $12 \%$ majstrów i czeladników. To znacznie poniżej średniej dla całego okręgu Izby Rzemieślniczej w Lublinie, która podawała, że cechy zrzeszają 23\% ogółu zatrudnionych w zakładach ${ }^{55}$.

Tabela 2. Liczba cechów żydowskich w Lublinie oraz ich liczebność w latach 1930-1937*

\begin{tabular}{|c|c|c|}
\hline Rok & Liczba cechów & Liczba członków w cechach \\
\hline 1930 & 19 & 626 \\
\hline 1931 & 19 & 777 \\
\hline 1932 & b.d. & 666 \\
\hline 1933 & b.d. & 548 \\
\hline 1934 & 15 & 571 \\
\hline 1935 & 16 & 604 \\
\hline 1936 & 9 & 458 \\
\hline 1937 & 9 & 474 \\
\hline
\end{tabular}

* W sprawozdaniu Izby Rzemieślniczej w Lublinie za rok 1932 nie podano danych na temat liczby żydowskich cechów na terenie Lublina. W sprawozdaniu za rok 1933 podane zostały tylko dane dotyczące liczby członków lubelskich cechów (z podziałem na chrześcijan i Żydów). Zob.: III Sprawozdanie Izby Rzemieślniczej w Lublinie..., tablica nr 4b; IV Sprawozdanie Izby Rzemieślniczej w Lublinie..., s. 42.

Źródło: opracowanie własne na podstawie danych (b.d. oznacza brak danych) zawartych w sprawozdaniach Izby Rzemieślniczej w Lublinie z lat 1930-1937.

53 „Rękodzieło i Przemysł” (18 kwietnia 1936), nr 5, s. 3.

${ }^{54}$ W latach 1932 i 1933 w sprawozdaniach Izby Rzemieślniczej w Lublinie nie podano szczegółowych informacji uwzględniających dane osobowe starszych cechów.

${ }^{55}$ IV Sprawozdanie Izby Rzemieślniczej w Lublinie..., s. 42. 
Tabela 3. Starsi lubelskich cechów żydowskich w latach 1930-1937

\begin{tabular}{|c|c|c|c|c|c|c|}
\hline \multirow{2}{*}{ Lp. } & \multirow{2}{*}{ Nazwa cechu } & \multicolumn{5}{|c|}{ Starszy cechu w poszczególnych latach } \\
\hline & & 1930 & 1931 & 1934 & 1936 & 1937 \\
\hline 1 & $\begin{array}{l}\text { Lubelski Cech } \\
\text { Krawców }\end{array}$ & $\begin{array}{c}\text { Chaim } \\
\text { Sznajderman }\end{array}$ & $\begin{array}{c}\text { Abram } \\
\text { Fingergut- } \\
\text { man }\end{array}$ & $\begin{array}{c}\text { Uszer } \\
\text { Cymerman }\end{array}$ & $\begin{array}{l}\text { Izrael } \\
\text { Gertler }\end{array}$ & $\begin{array}{l}\text { Izrael } \\
\text { Gertler }\end{array}$ \\
\hline 2 & $\begin{array}{l}\text { Lubelski Cech } \\
\text { Kuśnierzy }\end{array}$ & $\begin{array}{l}\text { Moszek } \\
\text { Blejwajs }\end{array}$ & $\begin{array}{c}\text { Hersz } \\
\text { Lerman }\end{array}$ & $\begin{array}{c}\text { Hersz } \\
\text { Lerman }\end{array}$ & $\begin{array}{l}\text { Moszek } \\
\text { Blejwajs }\end{array}$ & $\begin{array}{l}\text { Moszek } \\
\text { Blejwajs }\end{array}$ \\
\hline 3 & $\begin{array}{l}\text { Lubelski Cech } \\
\text { Czapników } \\
\text { i Kapeluszników }\end{array}$ & $\begin{array}{l}\text { Mojżesz } \\
\text { Aron Lew }\end{array}$ & $\begin{array}{c}\text { Mojżesz } \\
\text { Aron Lew }\end{array}$ & $\begin{array}{c}\text { Mojżesz } \\
\text { Aron Lew }\end{array}$ & \multicolumn{2}{|c|}{ nie działał } \\
\hline 4 & $\begin{array}{l}\text { Lubelski Cech } \\
\text { Złotniczo-Jubi- } \\
\text { lersko-Grawer- } \\
\text { sko-Brązowniczy }\end{array}$ & $\begin{array}{l}\text { Aleksander } \\
\text { Lewi }\end{array}$ & $\begin{array}{c}\text { Szyja } \\
\text { Zygielman }\end{array}$ & $\begin{array}{c}\text { Szyja } \\
\text { Zygielman }\end{array}$ & \multicolumn{2}{|c|}{ nie działał } \\
\hline 5 & $\begin{array}{l}\text { Lubelski Cech } \\
\text { Szklarzy }\end{array}$ & $\begin{array}{l}\text { Srul-Majer } \\
\text { Erlich }\end{array}$ & $\begin{array}{l}\text { Srul-Majer } \\
\text { Erlich }\end{array}$ & $\begin{array}{l}\text { Srul-Majer } \\
\text { Erlich }\end{array}$ & \multicolumn{2}{|c|}{ nie działał } \\
\hline 6 & $\begin{array}{l}\text { Lubelski Cech } \\
\text { Ślusarzy } \\
\text { i Kotlarzy }\end{array}$ & $\begin{array}{c}\text { Josef } \\
\text { Szwarcberg }\end{array}$ & $\begin{array}{c}\text { Josef } \\
\text { Goldman }\end{array}$ & $\begin{array}{c}\text { Josef } \\
\text { Goldman }\end{array}$ & \multicolumn{2}{|c|}{ nie działał } \\
\hline 7 & $\begin{array}{l}\text { Lubelski Cech } \\
\text { Rymarzy } \\
\text { i Tapicerów }\end{array}$ & Jakób Gartel & Aron Bass & Aron Bass & \multicolumn{2}{|c|}{ nie działał } \\
\hline 8 & $\begin{array}{l}\text { Lubelski Cech } \\
\text { Zegarmistrzów }\end{array}$ & $\begin{array}{c}\text { Abram- } \\
\text {-Zajwel } \\
\text { Blumenberg }\end{array}$ & $\begin{array}{l}\text { Abram } \\
\text { Blumen- } \\
\text { berg }\end{array}$ & $\begin{array}{l}\text { Abram } \\
\text { Blumen- } \\
\text { berg }\end{array}$ & \multicolumn{2}{|c|}{ nie działał } \\
\hline 9 & $\begin{array}{l}\text { Powszechny } \\
\text { Cech Krawców }\end{array}$ & $\begin{array}{c}\text { Chuna } \\
\text { Szturcman }\end{array}$ & $\begin{array}{c}\text { Chuna } \\
\text { Szturcman }\end{array}$ & \multicolumn{3}{|c|}{ nie działał } \\
\hline 10 & $\begin{array}{l}\text { Powszechny } \\
\text { Cech Stolarzy }\end{array}$ & $\begin{array}{c}\text { Szyja } \\
\text { Hercman }\end{array}$ & $\begin{array}{c}\text { Szyja } \\
\text { Hercman }\end{array}$ & \multicolumn{3}{|c|}{ nie działał } \\
\hline 11 & $\begin{array}{l}\text { Lubelski Cech } \\
\text { Blacharzy }\end{array}$ & $\begin{array}{c}\text { Fiszel Zaj- } \\
\text { densznyr }\end{array}$ & $\begin{array}{c}\text { Fiszel Zaj- } \\
\text { densznyr }\end{array}$ & $\begin{array}{c}\text { Fiszel Zaj- } \\
\text { densznyr }\end{array}$ & \multicolumn{2}{|c|}{ nie działał } \\
\hline 12 & $\begin{array}{c}\text { Lubelski Cech } \\
\text { Malarzy }\end{array}$ & $\begin{array}{c}\text { Lejb } \\
\text { Goldberg }\end{array}$ & $\begin{array}{c}\text { Lejb } \\
\text { Goldberg }\end{array}$ & $\begin{array}{c}\text { Hersz } \\
\text { Grosbard }\end{array}$ & \multicolumn{2}{|c|}{ nie działał } \\
\hline 13 & $\begin{array}{l}\text { Lubelski Cech } \\
\text { Szewców } \\
\text { i Cholewkarzy* }\end{array}$ & $\begin{array}{c}\text { Szyja } \\
\text { Holcman }\end{array}$ & $\begin{array}{c}\text { Szyja } \\
\text { Holcman }\end{array}$ & $\begin{array}{c}\text { Szyja } \\
\text { Holcman }\end{array}$ & $\begin{array}{c}\text { Szyja } \\
\text { Holcman }\end{array}$ & $\begin{array}{c}\text { Szyja } \\
\text { Holcman }\end{array}$ \\
\hline 14 & $\begin{array}{l}\text { Lubelski Cech } \\
\text { Szczotkarzy }\end{array}$ & $\begin{array}{c}\text { Noech } \\
\text { Wajsmarder }\end{array}$ & $\begin{array}{c}\text { Noech } \\
\text { Wajsmarder }\end{array}$ & $\begin{array}{c}\text { Noech } \\
\text { Wajsmarder }\end{array}$ & \multicolumn{2}{|c|}{ nie działał } \\
\hline 15 & $\begin{array}{l}\text { Powszechny } \\
\text { Cech Malarzy }\end{array}$ & Szloma Bass & $\begin{array}{l}\text { Szloma } \\
\text { Bass }\end{array}$ & \multicolumn{3}{|c|}{ nie działał } \\
\hline 16 & $\begin{array}{l}\text { Powszechny } \\
\text { Cech Szewców } \\
\text { i Cholewkarzy }\end{array}$ & $\begin{array}{l}\text { Szyja Lejb } \\
\text { Himelblum }\end{array}$ & $\begin{array}{c}\text { Szyja Lejb } \\
\text { Himelblum }\end{array}$ & \multicolumn{3}{|c|}{ nie działał } \\
\hline
\end{tabular}




\begin{tabular}{|c|c|c|c|c|c|c|}
\hline 17 & $\begin{array}{l}\text { Lubelski Cech } \\
\text { Piekarzy } \\
\text { i Cukierników }\end{array}$ & $\begin{array}{c}\text { Mordko } \\
\text { Bajtel }\end{array}$ & $\begin{array}{c}\text { Mordko } \\
\text { Bajtel }\end{array}$ & $\begin{array}{c}\text { Mordko } \\
\text { Bajtel }\end{array}$ & $\begin{array}{l}\text { Mordko } \\
\text { Sznajfeld }\end{array}$ & $\begin{array}{l}\text { Mordko } \\
\text { Sznajfeld }\end{array}$ \\
\hline 18 & $\begin{array}{c}\text { Lubelski Cech } \\
\text { Rzeźników } \\
\text { i Wędliniarzy }\end{array}$ & $\begin{array}{l}\text { Szol-Motel } \\
\text { Goldberg }\end{array}$ & $\begin{array}{c}\text { Szyja } \\
\text { Goldberg }\end{array}$ & $\begin{array}{l}\text { brak } \\
\text { danych }\end{array}$ & $\begin{array}{c}\text { Lejb } \\
\text { Kestelman }\end{array}$ & $\begin{array}{c}\text { Lejb } \\
\text { Kestelman }\end{array}$ \\
\hline 19 & $\begin{array}{c}\text { Lubelski Cech } \\
\text { Stolarzy }\end{array}$ & nie działał & $\begin{array}{c}\text { Izrael Fin- } \\
\text { kelsztajn }\end{array}$ & $\begin{array}{l}\text { Izrael Fin- } \\
\text { kelsztajn }\end{array}$ & $\begin{array}{c}\text { Izrael Fin- } \\
\text { kelsztajn }\end{array}$ & $\begin{array}{c}\text { Izrael Fin- } \\
\text { kelsztajn }\end{array}$ \\
\hline 20 & $\begin{array}{c}\text { Lubelski Cech } \\
\text { Fryzjerów } \\
\text { i Perukarzy }\end{array}$ & nie $\mathrm{c}$ & iałał & Chil Gaus & $\begin{array}{c}\text { Aron } \\
\text { Fiszman }\end{array}$ & $\begin{array}{l}\text { Chaim } \\
\text { Prymer }\end{array}$ \\
\hline 21 & $\begin{array}{c}\text { Lubelski Cech } \\
\text { Męskich } \\
\text { i Damskich } \\
\text { Krawców }\end{array}$ & \multicolumn{3}{|c|}{ nie działał } & $\begin{array}{c}\text { Henoch } \\
\text { Akerman }\end{array}$ & $\begin{array}{l}\text { Henoch } \\
\text { Akerman }\end{array}$ \\
\hline 22 & $\begin{array}{l}\text { Drugi Lubelski } \\
\text { Cech Fryzjerów }\end{array}$ & \multicolumn{3}{|c|}{ nie działał } & $\begin{array}{l}\text { Szmul Lejb } \\
\text { Zemelman }\end{array}$ & $\begin{array}{l}\text { Szmul Lejb } \\
\text { Zemelman }\end{array}$ \\
\hline
\end{tabular}

* Od roku 1936 - Lubelski Cech Zawodów Skórzanych.

Źródło: opracowanie własne na podstawie danych zawartych w sprawozdaniach Izby Rzemieślniczej w Lublinie z lat 1930-1937.

Spośród wszystkich rodzajów rzemiosł najlepiej w Lublinie zorganizowani byli żydowscy krawcy. W latach trzydziestych działały tu dwa cechy zrzeszające wykonujących ten zawód. Powszechny Cech Krawców, który zakończył działalność w 1931 r., skupiał 30 członków w roku 1930 i 28 w 1931. Znacznie liczniejszy był Lubelski Cech Krawców, który w swoim apogeum przypadającym na rok 1936 zrzeszał 151 członków.

Drugim po krawcach zawodem, w którym odnotowano największą liczbę należących do cechów rzemieślników, byli szewcy i cholewkarze. Podobnie jak w przypadku krawców w tej profesji także działały dwa cechy, z których mniej liczny - Powszechny Cech Szewców i Cholewkarzy zakończył działalność w roku 1931. W 1930 r. należało do niego 18, a rok później - 20 członków. Drugim był Lubelski Cech Szewców i Cholewkarzy (od 1936 r. Lubelski Cech Zawodów Skórzanych). W 1931 r. należało do niego 107 osób, a w ostatnim roku sprawozdawczym - 67.

Trzecim najliczniejszym zrzeszeniem rzemieślników żydowskich w Lublinie był Lubelski Cech Rzeźników i Wędliniarzy, który w 1937 r. mógł pochwalić się liczbą 82 członków. W omawianym okresie działały na terenie miasta w sumie 22 żydowskie cechy, które - wraz z ich stanem liczebnym zostały przedstawione w tabeli 4 . 
Tabela 4. Wykaz żydowskich cechów w Lublinie oraz ich liczebność w latach 1930-1937 (b.d. oznacza brak danych)

\begin{tabular}{|c|c|c|c|c|c|c|c|c|c|}
\hline \multirow{2}{*}{ Lp. } & \multirow{2}{*}{ Nazwa cechu } & \multicolumn{8}{|c|}{ Liczba członków w poszczególnych latach } \\
\hline & & 1930 & 1931 & 1932 & 1933 & 1934 & 1935 & 1936 & 1937 \\
\hline 1 & Lubelski Cech Krawców & 122 & 125 & b.d. & b.d. & 112 & b.d. & 151 & 123 \\
\hline 2 & Lubelski Cech Kuśnierzy & 35 & 32 & b.d. & b.d. & 35 & b.d. & 26 & 24 \\
\hline 3 & $\begin{array}{c}\text { Lubelski Cech Czapników i Kape- } \\
\text { luszników }\end{array}$ & 25 & 33 & b.d. & b.d. & 31 & b.d. & \multicolumn{2}{|c|}{ nie działał } \\
\hline 4 & $\begin{array}{l}\text { Lubelski Cech Złotniczo- } \\
\text {-Jubilersko-Grawersko- } \\
\text {-Brązowniczy }\end{array}$ & 17 & 24 & b.d. & b.d. & 23 & b.d. & \multicolumn{2}{|c|}{ nie działał } \\
\hline 5 & Lubelski Cech Szklarzy & 17 & 20 & b.d. & b.d. & 17 & b.d. & \multicolumn{2}{|c|}{ nie działał } \\
\hline 6 & Lubelski Cech Ślusarzy i Kotlarzy & 25 & 25 & b.d. & b.d. & 25 & b.d. & \multicolumn{2}{|c|}{ nie działał } \\
\hline 7 & $\begin{array}{c}\text { Lubelski Cech Rymarzy i Tapi- } \\
\text { cerów }\end{array}$ & 22 & 28 & b.d. & b.d. & 19 & b.d. & \multicolumn{2}{|c|}{ nie działał } \\
\hline 8 & Lubelski Cech Zegarmistrzów & 24 & 28 & b.d. & b.d. & 20 & b.d. & \multicolumn{2}{|c|}{ nie działał } \\
\hline 9 & Powszechny Cech Krawców & 30 & 28 & \multicolumn{6}{|c|}{ nie działał } \\
\hline 10 & Powszechny Cech Stolarzy & 20 & 24 & \multicolumn{6}{|c|}{ nie działał } \\
\hline 11 & Lubelski Cech Blacharzy & 17 & 29 & b.d. & b.d. & 12 & b.d. & \multicolumn{2}{|c|}{ nie działał } \\
\hline 12 & Lubelski Cech Malarzy & 34 & 40 & b.d. & b.d. & 26 & b.d. & \multicolumn{2}{|c|}{ nie działał } \\
\hline 13 & $\begin{array}{c}\text { Lubelski Cech Szewców i Cholew- } \\
\text { karzy (od } 1936 \text { r. Lubelski Cech } \\
\text { Zawodów Skórzanych) }\end{array}$ & 74 & 107 & b.d. & b.d. & 89 & b.d. & 60 & 67 \\
\hline 14 & Lubelski Cech Szczotkarzy & 15 & 17 & b.d. & b.d. & 18 & b.d. & \multicolumn{2}{|c|}{ nie działał } \\
\hline 15 & Powszechny Cech Malarzy & 14 & 26 & \multicolumn{6}{|c|}{ nie działał } \\
\hline 16 & $\begin{array}{l}\text { Powszechny Cech Szewców } \\
\text { i Cholewkarzy }\end{array}$ & 18 & 20 & \multicolumn{6}{|c|}{ nie działał } \\
\hline 17 & $\begin{array}{c}\text { Lubelski Cech Piekarzy i Cukier- } \\
\text { ników }\end{array}$ & 71 & 63 & b.d. & b.d. & 55 & b.d. & 45 & 55 \\
\hline 18 & $\begin{array}{c}\text { Lubelski Cech Rzeźników i Węd- } \\
\text { liniarzy }\end{array}$ & 45 & 63 & b.d. & b.d. & b.d. & b.d. & 54 & 82 \\
\hline 19 & Lubelski Cech Stolarzy & 17 & 45 & b.d. & b.d. & 38 & b.d. & 25 & 24 \\
\hline 20 & $\begin{array}{l}\text { Lubelski Cech Fryzjerów i Peru- } \\
\text { karzy }\end{array}$ & \multicolumn{4}{|c|}{ nie działał } & 51 & b.d. & 30 & 25 \\
\hline 21 & $\begin{array}{l}\text { Lubelski Cech Męskich i Dam- } \\
\text { skich Krawców }\end{array}$ & \multicolumn{6}{|c|}{ nie działał } & 29 & 30 \\
\hline 22 & Drugi Lubelski Cech Fryzjerów & \multicolumn{6}{|c|}{ nie działał } & 38 & 44 \\
\hline
\end{tabular}

Źródło: opracowanie własne na podstawie danych zawartych w sprawozdaniach Izby Rzemieślniczej w Lublinie z lat 1930-1937. 
Sytuacja finansowa żydowskich cechów w Lublinie w tym okresie nie była najlepsza. Członkowie nagminnie zalegali z płatnością składek, co dodatkowo negatywnie odbijało się na stanie finansów cechów. Najgorszy pod tym względem był rok 1931, kiedy suma zaległości ponaddwukrotnie przewyższyła majątek wszystkich żydowskich cechów w Lublinie ${ }^{56}$. W następnych latach poprawiono co prawda ściągalność składek, jednak kwota zobowiązań członków z tego tytułu była nadal znacząca w stosunku do majątku tych organizacji (w roku 1936 było to 56\%, w roku 1937 zaś $31 \%$ majątku cechów). Zmniejszenie sumy zaległości z tytułu składek w ostatnich latach sprawozdawczych miało także związek ze spadkiem liczby członków cechów. Składki opłacano raz na rok, a ich wysokość wahała się od 3 do $20 \mathrm{zt}^{57}$.

Przedstawiając stan finansów żydowskich cechów w Lublinie, można zauważyć wyraźną dysproporcję ich stanu posiadania w stosunku do majątku cechów chrześcijańskich. W roku 1935 majątek wszystkich działających w mieście cechów szacowano na 65748 zł 58 gr, z czego 64301 zł 26 gr, czyli aż $99 \%$, przypadało na organizacje chrześcijańskie ${ }^{58}$. Stan finansów cechów żydowskich w latach 1931-1937 obrazuje tabela 5.

Tabela 5. Finanse żydowskich cechów w Lublinie w latach 1931-1937 (w zł; b.d. oznacza brak danych)

\begin{tabular}{|c|c|c|c|c|}
\hline Rok & Dochody & Wydatki & Majątek & Suma zaległości z tytułu składek \\
\hline 1931 & 11672,00 & 10178,00 & 1499,00 & 4396 \\
\hline 1932 & b.d. & b.d. & b.d. & b.d. \\
\hline 1933 & b.d. & b.d. & b.d. & b.d. \\
\hline 1934 & 5785,04 & 4837,47 & 1794,23 & b.d. \\
\hline 1935 & 6232,13 & 5795,82 & 1447,32 & b.d. \\
\hline 1936 & 6097,20 & 6273,19 & 2396,47 & 1338 \\
\hline 1937 & 7393,13 & 6265,70 & 4375,53 & 1362,80 \\
\hline
\end{tabular}

Źródło: opracowanie własne na podstawie danych zawartych w sprawozdaniach Izby Rzemieślniczej w Lublinie z lat 1931-1937.

${ }^{56}$ Suma zaległych składek w tym roku wyniosła 4396 zł, podczas gdy suma majątków cechów - 1499 zł. Zob. II Sprawozdanie Izby Rzemieślniczej w Lublinie..., s. 34-37.

${ }^{57}$ VII Sprawozdanie Izby Rzemieślniczej w Lublinie za rok 1936, Lublin 1937, s. 89-91.

${ }^{58}$ VI Sprawozdanie Izby Rzemieślniczej w Lublinie..., s. 94-95. 


\title{
Inne żydowskie organizacje rzemieślnicze
}

Cechy nie były jedynymi organizacjami zrzeszającymi rzemieślników żydowskich w Lublinie. Do 1925 r. działała w mieście jedna organizacja rzemieślników Żydów, która znajdowała się pod politycznym wpływem Jidisze Fołks-Partaj in Pojln (tzw. fołkiści).

Powstanie dwóch konkurencyjnych stowarzyszeń rzemieślniczych było efektem rozłamu w środowisku lubelskich rzemieślników, do którego doszło w 1926 r. na tle politycznym i ekonomicznym. W „Księdze Lublina” odnotowano:

\begin{abstract}
Stopniowo sprzeczności między różnymi grupami społecznymi, które należały do związku [rzemieślniczego], stawały się coraz ostrzejsze. Cześć najbogatszych majstrów faktycznie przekształciła się w małych przedsiębiorców, których interesy stopniowo stawały się takie same jak kupców i konfekcjonerów. Sytuacja stała się paradoksalna, gdyż związek rzemieślniczy, który powinien był bronić interesów chałupników i drobnych rzemieślników w stosunkach z ich pracodawcami, prowadzony był przez ludzi, których interesy stały się całkowicie identyczne z interesami tychże konfekcjonerów. Rozpoczęła się ostra walka w związku między tzw. młodymi majstrami i starymi. Walka ta przybrała charakter polityczny: przywódcy związku, „starzy”, byli fołkistami; opozycja, czyli „młodzi” - bundystami. Jednak była to walka przede wszystkim między grupami, które należały już do różnych warstw społecznych. Była to więc walka klas między chałupnikiem, zainteresowanym, aby otrzymywać wyższą płacę za swoją pracę, i zamożnym rzemieślnikiem, który częściowo lub całkowicie sam już był pracodawcą dającym, pośrednio lub bezpośrednio, pracę chałupnikom ${ }^{59}$.
\end{abstract}

„Młodzi”, wśród których przeważali związani z Bundem drobni rzemieślnicy i chałupnicy, zorganizowali się we frakcję, co z kolei spotkało się z represjami ze strony zarządu związku. Zarząd zagroził bowiem, że znajdujący się pod jego wpływem bank rzemieślniczy nie będzie dyskontował weksli, którymi powszechnie w owym czasie płacono drobnym rzemieślnikom i chałupnikom. Buntownikom udało się jednak podjąć negocjacje z dwoma bankami (przy Krakowskim Przedmieściu 4 i Bankiem Handlowym na ul. Lubartowskiej), które zobowiązały się zrealizować ich weksle. Oczywiście oba, wykorzystując położenie rzemieślników, zażądały wyższego dyskonta niż w innych bankach, korzystniejszego jednak niż u ulicznych spekulantów. Zarząd związku, widząc swoją porażkę, próbował negocjować. Obiecał, że będzie realizował weksle każdemu, kto podpisze

${ }^{59}$ Dos bukh fun Lublin..., s. 285-286. Wszystkie przekłady cytatów, jeśli nie są oznaczone inaczej, zostały dokonane przez autora artykułu. 
deklarację przystąpienia do Partii Ludowej. Kiedy to nie pomogło, zaczął usuwać zbuntowanych rzemieślników ze związku. Niedługo potem zwołali oni zebranie założycielskie nowego związku, które odbyło się w sali związku drobnych sklepikarzy przy ul. Szewskiej ${ }^{60}$.

Po tych wydarzeniach w Lublinie w latach trzydziestych działały dwie żydowskie organizacje o charakterze stowarzyszeń. Pierwszą z nich była Rada Rzemieślników Żydów Miasta Lublina związana z Żydowską Partią Ludową (tzw. fołkistami), kierowana przez inż. Henryka Bekkera. W 1937 r. Rada skupiała 343 członków, będąc najliczniejszym i najaktywniejszym stowarzyszeniem działającym w środowisku rzemieślników żydowskich w Lublinie ${ }^{61}$. Rada prowadziła sekretariat, który wspomagał członków oraz współpracujące z nią cechy żydowskie, a przy organizacji działały: świetlica, czytelnia i tani bufet dla bezrobotnych rzemieślników (w miesiącach zimowych). W lokalu Rady, który mieścił się przy Krakowskim Przedmieściu 26, miały także siedziby afiliowane przy niej instytucje, jak kasa bezprocentowa i kasa spółdzielcza ${ }^{62}$. Skupieni w Radzie rzemieślnicy płacili miesięcznie składki w wysokości 12 zł ${ }^{63}$.

Drugą organizacją, która działała na rzecz rzemieślników żydowskich, był lubelski oddział Związku Rzemieślników w Rzeczypospolitej Polskiej. W 1937 r. należało do niego 180 członków. Była to organizacja związana z socjalistyczną partią Bund, a jej siedziba mieściła się przy ul. Rybnej $1^{64}$. Prezesem oddziału lubelskiego był Lejb Ryngiel. Związek aktywnie angażował się w obronę praw pracowniczych osób zatrudnionych w rzemiośle, udało mu się m.in. wywalczyć poprawę warunków pracy krawców, czapników i szewców, prowadził też akcje dożywiania bezrobotnych rzemieślników i chałupników, wydając w 1937 r. dziennie 100 porcji chleba i herbaty. Rzemieślnicy, którzy należeli do tej organizacji, płacili miesięcznie 24 zł składki członkowskiej65. Związek działał do 9 lutego 1939 r., kiedy to decyzją Komisarza Rządu na Miasto Stołeczne Warszawę został rozwiązany pod zarzutem prowadzenia działalności niezgodnej ze statutem organizacji ${ }^{66}$. Wraz z centralą w stan likwidacji postawiono także lokalne oddziały związku.

\footnotetext{
${ }^{60}$ Tamże.

${ }^{61}$ VIII Sprawozdanie Izby Rzemieślniczej w Lublinie..., s. 122.

${ }^{62}$ VII Sprawozdanie Izby Rzemieślniczej w Lublinie..., s. 108.

3 Tamże.

${ }^{64}$ VIII Sprawozdanie Izby Rzemieślniczej w Lublinie..., s. 118.

${ }^{65}$ Tamże, s. 122-123.

${ }^{66}$ APL, Starostwo Powiatowe Lubelskie, sygn. 243.
} 


\section{Kredytowanie rzemiosła}

W okresie międzywojennym w Lubinie funkcjonowały dwie instytucje kredytowe, których działalność była ściśle ukierunkowana na potrzeby rzemieślników żydowskich. Obie miały charakter spółdzielni.

Bank Spółdzielczy dla Chałupników i Rzemieślników w Lublinie mieścił się przy ul. Lubartowskiej 15 i działał od 23 kwietnia 1928 r. ${ }^{67}$ Jego prezesem był związany z Bundem Ber Krempel. Bank skupiał 292 spółdzielców żydowskich, w tym 185 rzemieślników i chałupników, a jego działalność w latach trzydziestych wykazywała tendencje rozwojowe, o czym świadczy wzrost kapitału udziałowego z 11273 zł w 1935 r. do 15372 zł w końcu roku 1937. Wysokość jednego udziału wynosiła 25 zł (odpowiedzialność członków - 250 zł). W 1937 r. bank udzielił pożyczek na kwotę 186143 zł, z czego $60 \%$ udzielono rzemieślnikom i chałupnikom ${ }^{68}$. Zadania banku przedstawiono w druku ulotnym kolportowanym w Lublinie tuż po otwarciu instytucji. Należały do nich: udzielanie członkom wszelkiego rodzaju kredytu, przyjmowanie wkładów oszczędnościowych i lokat kapitału, inkasowanie weksli, frachtów itd., wydawanie przekazów, czeków i akredytyw oraz załatwianie innych czynności wchodzących w zakres działalności bankowej ${ }^{69}$.

Tabela 6. Pożyczki udzielone przez żydowskie instytucje kredytowe w Lublinie w latach 1933-1937 (w zł)

\begin{tabular}{|c|c|c|}
\hline Rok & $\begin{array}{c}\text { Bank Spółdzielczy dla Chałupników } \\
\text { i Rzemieślników }\end{array}$ & Spółdzielcza Kasa Rzemieślnicza \\
\hline 1933 & $355536,43^{*}$ & b.d. \\
\hline 1934 & 167007,00 & 19966,49 \\
\hline 1935 & 183475,06 & 38773,40 \\
\hline 1936 & 104167,16 & 40017,79 \\
\hline 1937 & 186142,74 & 49114,70 \\
\hline Razem & 996328,39 & 147872,38 \\
\hline
\end{tabular}

* W tym dla rzemieślników 225283,55 zł.

Źródło: opracowanie własne na podstawie danych zawartych w sprawozdaniach Izby Rzemieślniczej w Lublinie z lat 1933-1937.

${ }^{67}$ Ulotka informująca o rozpoczęciu działalności przez Bank Spółdzielczy dla Chałupników i Rzemieślników w Lublinie, 23 kwietnia 1928, http://polishjews.yivoarchives.org [dostęp: 2 listopada 2018].

${ }_{68}$ VIII Sprawozdanie Izby Rzemieślniczej w Lublinie..., s. 149.

${ }^{69} \mathrm{http}: / /$ polishjews.yivoarchives.org [dostęp: 2 listopada 2018]. 
Drugą żydowską instytucją kredytową w mieście była Spółdzielcza Kasa Rzemieślnicza w Lublinie z siedzibą przy Krakowskim Przedmieściu 26. Kasa powstała w 1933 r. z inicjatywy Rady Rzemieślników Żydów Miasta Lublina i obsługiwała przede wszystkim własnych członków. W 1937 r. w Kasie było 127 spółdzielców, z których 105 parało się rzemiosłem. Wysokość udziału określono na 25 zł, a odpowiedzialność członka - na pięciokrotność tej kwoty. Kapitał udziałowy Kasy w tym roku wynosił 3330 zł. Udzieliła ona pożyczek 624 spółdzielcom na łączną kwotę 49114 zł 70 gr. Prezesem tej instytucji był Mojżesz Aron Lew ${ }^{70}$. Wysokość pożyczek udzielonych przez obie instytucje wsparcia kredytowego w latach 1933-1937 obrazuje tabela 6 .

Banki spółdzielcze były nie tylko instytucjami kredytującymi bieżącą działalność produkcyjną lubelskiego rzemiosła, ale także placówkami dyskontującymi weksle, którymi zleceniodawcy i pracodawcy zwykli płacić rzemieślnikom za ich pracę. W okresie międzywojennym powszechną praktyką było, że chałupnicy i drobni rzemieślnicy nie otrzymywali wynagrodzenia w gotówce, ale w postaci weksla, który wystawca (był nim np. zlecający produkcję hurtownik) miał obowiązek zdyskontować w wyznaczonym terminie. Było to oczywiście niekorzystne dla rzemieślnika, który zapłatę za swoją pracę mógł otrzymać dopiero po upływie tego terminu. Aby zdobyć środki na utrzymanie, rzemieślnicy zmuszeni więc byli odsprzedawać weksle po znacznie zaniżonej cenie na drodze prywatnej, często ulicznym spekulantom, który pobierali prowizję za wcześniejsze zdyskontowanie weksla. Nierzadko takie praktyki stosowali nawet wystawcy weksli, którzy sami wykupywali je przed terminem płatności umownej. Oczywiście po cenie niższej niż nominalna:

W Lublinie często widywano obrazek, gdy rzemieślnik wychodził od konfekcjonera z wekslem, a przy drzwiach czekał już na niego przedstawiciel wystawcy, aby zawołać go do szefa w celu realizacji weksla. Tak więc kapitalista wykorzystywał swojego pracownika podwójnie: za pierwszym razem jako pracodawca, a potem jako lichwiarz ${ }^{71}$.

W wyniku takiego procederu rzemieślnik mógł stracić od 10 do $25 \%$ wartości i tak niezbyt wysokiej wypłaty. Aby zminimalizować takie praktyki, rzemieślnicze banki spółdzielcze podjęły się dyskontowania weksli przed terminem ich wykupu przez wystawcę. Oczywiście także te instytucje

${ }^{70}$ VIII Sprawozdanie Izby Rzemieślniczej w Lublinie..., s. 149.

${ }^{71}$ Dos bukh fun Lublin..., s. 285. 
pobierały opłaty za wcześniejsze ich wykupienie, starano się jednak, aby wysokość dyskonta była jak najniższa ${ }^{72}$.

Inną formą kredytowania, z której korzystało także rzemiosło żydowskie, były bezprocentowe kasy pożyczkowe. Działalność kas opierała się na współpracy ze związanymi z żydowską ortodoksją towarzystwami dobroczynnymi Gemiłes Chesed (hebr. gemilut chesed - dobry uczynek). Aby łatwiej dotrzeć do drobnych przedsiębiorców ze sfer ortodoksyjnych, przyjmowano dla nich właśnie tę tradycyjną nazwę. W zaborze rosyjskim tego typu instytucje po raz pierwszy pojawiły się w Wilnie w 1898 r., a w przededniu wybuchu I wojny światowej było ich już 178 z przeszło 100 tys. członków ${ }^{73}$.

W ostatnim okresie wojny i tuż po niej, korzystając z pomocy towarzystw dobroczynnych, zakładano tzw. Komitety Ratunkowe, które działały niemal we wszystkich miastach Polski. Komitety subwencjonowano ze środków żydowskich zagranicznych instytucji pomocowych, a do ich zadań należała także doraźna, materialna pomoc dla rzemieślników Żydów. Rozdawały one żywność, odzież, obuwie itd. ${ }^{74} \mathrm{~W}$ gestii komitetów leżały także bezprocentowe kasy pożyczkowe, które od 1926 r. funkcjonowały osobno, na ujednoliconych zasadach, a znaczna część środków, jakimi dysponowały na cele statutowe, pochodziła ze zwrotnej dotacji American Jewish Joint Distribution Committee (w skrócie: JDC lub Joint). Instytucja ta udzielała kasom długoterminowych (8-10-letnich), przyznawanych dwa razy do roku kredytów do wysokości 50\% kapitału obrotowego, spłacanych w półrocznych ratach $^{75}$.

Kasy działały na zasadzie stowarzyszeń, jednak z udzielanego przez nie wsparcia mogli korzystać nie tylko członkowie, ale również osoby spoza organizacji. Środków udzielano pod warunkiem przeznaczenia ich wyłącznie na cele wytwórcze lub handlowe. Kredyty udzielane przez kasy były z reguły niewysokie - od 200 do 300 zł na osobę, a pożyczkę spłacano w dziesięciu bezprocentowych ratach miesięcznych ${ }^{76}$.

Te skierowane przede wszystkim do najuboższych rzemieślników Żydów instytucje istniały niemal w każdym większym ośrodku na Lubelszczyźnie, ich działalność zaś była finansowana ze składek członkowskich, darowizn,

72 Tamże.

${ }^{73}$ Rafał Żebrowski, Gemilut Chesed, [w:] Polski stownik judaistyczny, https://www.jhi.pl/ psj/gemilut_chesed [dostęp: 20 grudnia 2019].

${ }_{74}$ Bornstein, Rzemiosto żydowskie w Polsce..., s. 105.

75 Tamże.

76 „Biuletyn Izby Rzemieślniczej w Lublinie” (1936), nr 3, s. 8. 
zapomóg rządowych i samorządowych, dochodów stowarzyszenia, pożyczek z centrali itd. ${ }^{77}$ Składki były dobrowolne i zazwyczaj niskie (wynosily 20 gr od zajmowanego przez rzemieślnika pokoju), a przy ich ściąganiu władze stowarzyszeń nie uciekały się do stosowania żadnych form nacisku na członków ${ }^{78}$.

Według informacji zawartych w sprawozdaniach Izby Rzemieślniczej w Lublinie w latach trzydziestych działała jedna tego typu kasa, częściowo zaspokajająca potrzeby finansowe rzemiosła. ${ }^{79}$ Sprawozdawcy nie podają nazwy tej instytucji, jednak z pewnością chodzi o Żydowską Kasę Pożyczkową Bezprocentową w Lublinie, która była prowadzona w formie stowarzyszenia i została zarejestrowana 20 września 1928 r. ${ }^{80}$ Siedziba Kasy mieściła się początkowo przy Krakowskim Przedmieściu 32, a w styczniu 1931 r. została przeniesiona ${ }^{81}$ do budynku przy ul. Staszica 10. Podobnie jak inne tego typu instytucje również lubelska Kasa wywodziła się z działalności Komitetu Ratunkowego i związanego z nim towarzystwa dobroczynnego Gemiłes Chesed ${ }^{82}$. W latach trzydziestych należała ona do ogólnopolskiej sieci CEKABE - Centrali Kas Bezprocentowych ${ }^{83}$.

Cele Kasy określał statut, który w artykule II stanowił, że jej zadaniem jest niesienie pomocy niezamożnym Żydom, mieszkańcom miasta Lublina, przez udzielanie pożyczek bezprocentowych dla polepszenia ich bytu gospodarczego. Pożyczki otrzymywano za poręczeniem, jednak statut dopuszczał sytuacje, w których zarząd mógł podjąć decyzję o udzieleniu wsparcia bez wymaganego poręczenia. Członkowie Kasy dzielili się na zwyczajnych, honorowych i wspierających ( $\mathrm{tj}$. nadzwyczajnych - można było nimi zostać po uiszczeniu jednorazowej opłaty w wysokości 50 zł), jednak tylko należący do dwóch pierwszych kategorii mieli prawo głosu na walnym zgromadzeniu. Aby wstąpić w szeregi stowarzyszenia i zostać członkiem Kasy, należało uiścić opłatę w wysokości 3 zł i opłacać miesięczną składkę, która w 1928 r. wynosiła 1 zł 50 gr. Konsekwencją nieopłacania składek mogło być wykreślenie z listy członków, decyzja o tym należała jednak do walnego zgromadzenia. Składki były jednym z kilku statutowych źródeł

${ }^{77}$ W roku 1936 działały na Lubelszczyźnie 62 takie kasy, które posiadały u swoich dłużników kapitał na sumę 850000 zł. Tamże.

78 „Biuletyn Izby Rzemieślniczej w Lublinie” (1936), nr 6, s. 6.

${ }^{79}$ II Sprawozdanie Izby Rzemieślniczej w Lublinie..., s. 156.

${ }^{80}$ APL, Starostwo Grodzkie Lubelskie [dalej: SGL], sygn. 34.

81 Tamże.

${ }^{82}$ Dos bukh fun Lublin..., s. 284.

${ }^{83}$ Było to właściwie Towarzystwo Popierania Kredytu Bezprocentowego i Produktywizacji Ludności Żydowskiej w Polsce. 
dochodu stowarzyszenia. Oprócz nich Kasa była finansowana z ofiar członków, osób prywatnych i instytucji, darowizn i zapisów, dochodów i majątku Kasy, dochodów z odczytów, wieczorków, przedstawień, koncertów i kwest oraz z ewentualnych zapomóg rządowych i samorządowych ${ }^{84}$.

W 1931 r. w zarządzie stowarzyszenia zasiadali m.in.: Bolesław Warman prezes, Lewek Krasucki - wiceprezes, Chaim Dawid Langfus - sekretarz. Po śmierci Warmana w roku 1932 prezesem został Dawid Karszman, który funkcję tę sprawował do wybuchu wojny ${ }^{85}$. Stanowisko wiceprezesa objął Dawid Dawidsohn, a funkcję skarbnika pełnił Josef Goldsztern. Z informacji przekazanej do Starostwa Grodzkiego w Lublinie wynika, że 17 października 1931 r. stowarzyszenie liczyło 240 członków zwyczajnych oraz 867 wspierających. Dwa lata później - 29 listopada 1933 r. -w piśmie do starostwa podawano, że stowarzyszenie liczy 926 członków. Wszyscy członkowie mieli prawo do korzystania $\mathrm{z}$ nieoprocentowanych pożyczek w wysokości 50 zł, które spłacano w ratach w wysokości 3 lub 5 zł ${ }^{86}$.

Stan finansowy Kasy według zachowanych dokumentów Starostwa Grodzkiego w Lublinie na początku lat trzydziestych wynosił 130 tys. zł. $\mathrm{Z}$ tego 60 tys. zł pochodziło z dotacji Banku Gospodarstwa Krajowego, 60 tys. zł ze wsparcia Jointu, 1 tys. zł ofiarowała lubelska Gmina Wyznaniowa, pozostałe środki pochodziły ze składek, kwest i kredytów. Od 1 kwietnia 1932 r. do 31 marca 1933 r. Kasa udzieliła pożyczek na kwotę 97691 zł $22 \mathrm{gr}^{87}$. W sprawozdaniu z 2 kwietnia 1938 r. zarząd stowarzyszenia podawał, że liczy ono 1372 członków, a kapitał obrotowy Kasy wynosił 132357 zł 21 gr. W 1937 r. Kasa udzieliła 1602 pożyczki ${ }^{88}$.

Żydowska Kasa Pożyczkowa Bezprocentowa w Lublinie nie była jedyną tego typu instytucją działającą na terenie miasta w omawianym okresie. Oprócz niej w środowisku ortodoksyjnym funkcjonowały jeszcze dwie inne kasy bezprocentowe: Lubelska Żydowska Bezprocentowa Kasa Pożyczkowa im. Froima i Hindy Bruchy Berlinerów i Kasa Bezprocentowa im. Rabina Meira Szapiry. Można przypuszczać, że również z ich oferty korzystali lubelscy rzemieślnicy żydowscy.

Pierwsza z nich miała siedzibę przy ul. Lubartowskiej 1 i została założona w 1903 r. (do rejestru stowarzyszeń wpisano ją 28 listopada 1922 r. pod pozycją 151). Kasa skupiała przede wszystkim drobnych kupców oraz

${ }^{84}$ APL, SGL, sygn. 34.

${ }^{85}$ Dos bukh fun Lublin ..., s. 284.

${ }^{86}$ APL, SGL, sygn. 34.

87 Tamże.

88 Tamże. 
ubogich handlarzy i była stosunkowo niewielką organizacją, której kapitał szacowano na ok. 15000 zł, a liczbę członków na ok. 500 osób opłacających miesięczną składkę w wysokości 30 gr. W 1931 r. Kasa udzieliła 611 pożyczek na kwotę 24835 zł. Prezesem zarządu był Mojżesz Ajzenberg, wiceprezesem - Dawid Funt, skarbnikiem - Szyja Nirenberg, a sekretarzem - Froim Żytomirski ${ }^{89}$.

Kasa Bezprocentowa im. Rabina Meira Szapiry była najmniejszą spośród wymienionych tu instytucji wsparcia bezprocentowego. Została założona pod koniec lat dwudziestych, a jej siedziba mieściła się w szpitalu żydowskim przy ul. Lubartowskiej 53. Przez około sześć lat jej działalność była prowadzona nieformalnie i dopiero na początku 1935 r. skupieni wokół niej członkowie podjęli starania o legalizację tej instytucji. W roku tym kapitał Kasy szacowano na $2500 \mathrm{zł}^{90}$. Również ta instytucja działała głównie wśród drobnych kupców i handlarzy.

Oprócz wymienionych wyżej form kredytowania działalności lubelscy rzemieślnicy żydowscy mogli korzystać z finansowej pomocy państwa udzielanej przez Bank Gospodarstwa Krajowego. Fundusze BGK były rozdzielane pośród rzemieślników za pośrednictwem Komunalnych Kas Oszczędności powołujących w tym celu Komitety Rozdzielcze, które zajmowały się rozpatrywaniem wniosków i przyznawaniem pożyczek. W 1933 r. w pięcioosobowym komitecie powołanym dla Lublina zasiadało dwóch rzemieślników żydowskich - cholewkarz Bencjon Tenenbaum i krawiec Uszer Cymerman. Z tej formy pomocy skorzystało w tym roku 46 rzemieślników Żydów, którym udzielono łącznie kredytu w wysokości 9250 zł (26 krawców - 5300 zł; 7 kuśnierzy - 1550 zł; 5 stolarzy - 1000 zł; 3 szewców - 450 zł; 2 kapeluszników - 400 zł; 1 rękawicznik - 250 zł; 1 tapicer - 150 zł; 1 szczotkarz - 150 zł) ${ }^{91}$. W 1935 r. udział rzemieślników Żydów korzystających z kredytu BGK wynosił 27,6\% $\%^{92}$.

\section{Żydzi w Izbie Rzemieślniczej w Lublinie}

Izba Rzemieślnicza w Lublinie została powołana na mocy przepisów Rozporządzenia Prezydenta Rzeczypospolitej z dnia 7 czerwca 1927 r.

${ }^{89}$ Tamże, sygn. 35.

90 Tamże, sygn. 36.

${ }^{91}$ APL, UWL, WP, sygn. 846.

92 Tamże. 
o prawie przemysłowem ${ }^{93}$. Będąc instytucją publiczną, miała obowiązek reprezentować interesy całego rzemiosła w okręgu lubelskim, a więc także rzemieślników Żydów. Mieli oni swoje przedstawicielstwo w składzie Izby, zarówno wśród członków, jak i w zarządzie tej instytucji.

W latach 1930-1937 żydowscy członkowie i zastępcy członków lubelskiej Izby Rzemieślniczej stanowili zwykle około jednej trzeciej jej składu. W roku 1930 w Izbie zasiadało 6 członków Żydów, w następnych latach było ich 7 na 20 miejsc. Podobnie wyglądały proporcje co do zastępców członków Izby. W latach 1930-1933 Żydzi obsadzali 7 na 20 stanowisk, a po zredukowaniu od roku 1934 liczby zastępców do 15 byli reprezentowani przez 5 osób. Widać tu, że skład Izby nie odzwierciedlał stosunków ilościowych, jakie panowały w rzemiośle w tym okręgu. Żydzi, stanowiąc większość, byli reprezentowani przez mniejszą niż chrześcijanie liczbę członków.

W zarządzie Izby żydowscy rzemieślnicy w latach trzydziestych obsadzali dwa stanowiska - wiceprzewodniczącego i członka zarządu. W okresie 1930-1933 pierwszą funkcję piastował Josef Zygiel, a drugą - Mojżesz Aron Lew. Od roku 1934 Lew zastąpił Zygiela na stanowisku wiceprzewodniczącego zarządu Izby, a na jego miejsce jako członka zarządu powołano Izraela Finkelsztajna. Obaj sprawowali swoje funkcje przynajmniej do roku 1937. Powyższa sytuacja odzwierciedla ogólnopolską tendencję w obsadzaniu kluczowych stanowisk w izbach polegającą na tym - jak pisze we wspomnieniach Baruch Elimelech Rak - że „przewodniczącym [izby] musiał być chrześcijanin, Żyd mógł być tylko wiceprzewodniczącym"94.

Ważną postacią wśród żydowskich pracowników tej instytucji był jej współzałożyciel, Mojżesz Gliksztejn. Początkowo pełnił funkcję skarbnika, a od 1931 r. kierował biurem oraz pracował na stanowisku referenta wydziałów gospodarczo-zawodowego oraz obciążeń rzemiosła, a także działów finansowo-budżetowego i gospodarczego w wydziale prezydialnym. W 1935 r. został kierownikiem wydziału ogólnego biura Izby, a zakres jego obowiązków obejmował: organizowanie zebrań radców Izby i posiedzeń zarządu, konferencje, komunikaty prasowe, wydawnictwa, sprawy personalno-organizacyjne, finansowe, rachunkowe oraz ustawodawstwo przemysłowe. Gliksztejn był też autorem artykułów i opracowań, zwłaszcza

${ }^{93}$ Otwarcie Izby odbyło się 1 grudnia 1929 r. w lokalu przy ul. Królewskiej 11. Podczas uroczystości w imieniu rzemieślników żydowskich przemawiał inż. Henryk Bekker, prezes Rady Rzemieślników Żydów Miasta Lublina. Zob.: tamże, sygn. 713.

${ }_{94}$ Baruch Elimelech Rak, Wspomnienia żydowskiego działacza rzemieślniczego, Warszawa 2010, s. 123. 
z problematyki zagadnień podatkowo-finansowych i socjalnych. W połowie lat trzydziestych został powołany na wicedyrektora Izby Rzemieślniczej w Lublinie, lecz na fali rosnących w Polsce nastrojów antysemickich zwolniono go $\mathrm{z}$ tej funkcji wiosną $1939 \mathrm{r} .{ }^{95}$

Wśród żydowskich urzędników Izby w sprawozdaniach wymieniana jest też Róża Zygiel, która w latach 1931-1932 roku kierowała wydziałem nr 1 zajmującym się nauką rzemiosła, a w roku 1937 figuruje w sprawozdaniu Izby jako referentka w wydziale uprawnień przemysłowych oraz osoba odpowiedzialna za bibliotekę i kasę Izby.

Analizując treść zachowanych „Biuletynów Izby Rzemieślniczej w Lublinie", można zauważyć, że sprawy z życia żydowskiej społeczności rzadko przebijały się na łamy tego periodyku. Biuletyn znacznie więcej uwagi poświęcał działalności chrześcijańskich organizacji, a bardzo niewiele miejsca przeznaczał na informacje o inicjatywach żydowskich, na przykład w latach 1936-1937 na łamach biuletynu regularnie i szczegółowo informowano o zjazdach organizacji chrześcijańskich, podczas gdy podobne wydarzenia w świecie rzemiosła żydowskiego bywały jedynie krótko odnotowywane. Rzemieślnicy żydowscy zarzucali Izbie, że faworyzuje środowisko chrześcijańskie, wspierając jego inicjatywy, a ignoruje działania rzemieślników Żydów.

Do takiego sporu, a także polemiki prasowej na łamach biuletynu oraz dziennika „Lubliner Tugblat” doszło z okazji wystawy rzemieślniczej, którą zorganizowano od 5 do 12 września 1937 r. w Lublinie z inicjatywy miejscowego Związku Rzemieślników Chrześcijan. Publicysta „Tugblatu”, Jakub Nisenbaum, zarzucał kierownictwu Izby, że otoczyło opieką wydarzenie, na którym pokazano jednostronny, bo tylko chrześcijański - i to bardzo wybiórczy - obraz lubelskiego rzemiosła. Nisenbaum podnosił też zarzut, że to Izba tak naprawdę była organizatorem wystawy i sfinansowała ją z publicznych pieniędzy. Pisał dziennikarz:

I jeszcze jedno małe pytanie. - Z jakiej kasy wypłaciła Izba Rzemieślnicza te tysiące złotych? Zdaje się, że pieniądze czerpała z takiej kasy, do której również i Żydzi wnoszą swe ciężko zapracowane grosze. Czy kierownictwo Izby Rzemieślniczej ma choć najmniejszą gwarancję, że ci, którzy dźwigają ciężar budżetu Izby, zgodziliby się, ażeby ich pieniądze zostały w ten sposób wydatkowane ${ }^{96}$.

${ }_{95}$ Adam Kopciowski, Ida Gliksztejn i jej rodzina. Losy do wybuchu wojny, [w:] Ida Gliksztejn, Pamiętnik z czasów wojny. Lublin, wrzesień 1939 - styczeń 1943, wstęp, posłowie i oprac. Adam Kopciowski, Lublin 2017, s. 33-37.

96 „Biuletyn Izby Rzemieślniczej w Lublinie” (1937), nr 6, s. 6-7. 
Izba przyjęła - fikcyjny zdaniem Nisenbauma - patronat, „byleby nie organizować wystawy pod własnym zasłużonym imieniem. Wówczas bowiem musiałoby się przeznaczyć miejsce również na stoiska dla żydowskich rzemieślników" $"$ p7.

W odpowiedzi na zarzuty żydowskiego dziennikarza Izba stwierdziła, że nie jest prawdą, aby „ukrywała się za jakikolwiek parawan, w szczególności parawan związków rzemieślniczych"98, a wsparcia dla inicjatywy związku chrześcijańskiego udzieliła, „bo wysoko ceni i uznaje za właściwe zaznaczanie współpracy organizacji z samorządem" "99. Natomiast na krytykę finansowania tego przedsięwzięcia ze wspólnych pieniędzy całego lubelskiego rzemiosła odpowiedziano, że „Izba Rzemieślnicza nie uwzględnia w statystyce wpływów podziału na sumy otrzymane od Żydów i od nie-Żydów i jak dotąd nie prowadziła również takiej statystyki w rubrykach wydatków, dlatego odpowiedzi na podobne pytanie nie będzie można udzielić" ${ }^{100}$.

\section{$* * *$}

Przedstawione w artykule informacje pozwalają stwierdzić, że rzemiosło żydowskie stanowiło niezwykle istotny element pejzażu gospodarczego międzywojennego Lublina. W znacznej mierze kształtowało jego charakter nie tylko gospodarczy, ale również społeczny, przede wszystkim poprzez działalność żydowskich instytucji rzemieślniczych. Będąc w większości, a w niektórych branżach zdecydowanie dominując nad chrześcijanami, rzemieślnicy Żydzi znajdowali się jednocześnie w o wiele gorszym położeniu ekonomicznym. Było to spowodowane ogólnie niekorzystną sytuacją materialną społeczności żydowskiej w Lublinie, ale także brakiem należytego wsparcia ze strony instytucji publicznych nie tylko dla rzemiosła, lecz także dla całej żydowskiej populacji miasta. Dysproporcje między polskim a żydowskim środowiskiem rzemieślniczym widać choćby na przykładzie stanu posiadania cechów żydowskich i chrześcijańskich. Te drugie były po prostu o wiele zamożniejsze, przez co ich możliwości kreowania życia społecznego w ramach środowiska czy wspierania inicjatyw gospodarczych także były znacznie większe.

\footnotetext{
97 Tamże.

98 Tamże, s. 7.

99 Tamże.

100 Tamże.
} 
Zaprezentowany w tym tekście obraz żydowskiego rzemiosła jest w oczywisty sposób niepełny, może być jednak przyczynkiem do dalszych badań nad tym zjawiskiem w międzywojennym Lublinie. Na opracowanie oczekuje zarówno jego społeczny wymiar, jak i polityczne zaplecze, które miało przemożny wpływ na działalność organizacji i instytucji wspierających żydowskie środowisko rzemieślnicze. Ze względu na brak źródeł pochodzących od samych organizacji rzemieślniczych i politycznych działających w tym środowisku jedynym żydowskim materiałem, na którym może oprzeć się badacz, pozostaje prasa. Jest to przede wszystkim organ lubelskiego Bundu - „Lubliner Sztyme”, który regularnie dostarczał informacji na temat problemów rzemieślników i chałupników w Lublinie, informując m.in. o różnego rodzaju akcjach na rzecz środowiska, działalności żydowskich instytucji rzemieślniczych czy o protestach i strajkach inicjowanych przez afiliowane przy Bundzie związki zawodowe. Drugim tytułem, w którym znaleźć można wiele cennych wiadomości na omawiany temat, jest wychodzący przez całe dwudziestolecie międzywojenne bezpartyjny dziennik „Lubliner Tugblat” ${ }^{101}$. Opracowanie tematyki żydowskiego rzemiosła w Lublinie pod kątem społeczno-politycznym będzie z pewnością cennym uzupełnieniem jego ilościowego ujęcia przedstawionego w niniejszym artykule.

\section{Bibliografia}

\section{1. Źródła archiwalne}

Archiwum Państwowe w Lublinie

Akta Miasta Lublina, Oddział Rachuby, sygn. 1074.

Starostwo Grodzkie Lubelskie, sygn. 34, 35, 36.

Starostwo Powiatowe Lubelskie, sygn. 243.

Urząd Wojewódzki Lubelski, Wydział Przemysłowy, sygn. 713, 835, 846.

\section{2. Źródła opublikowane}

[I] Sprawozdanie Izby Rzemieślniczej w Lublinie: 1) Ze stanu rzemiosła w 1930 r.

2) Z działalności za lata: 1929 i 1930, Lublin 1931.

II Sprawozdanie Izby Rzemieślniczej w Lublinie za rok 1931, Lublin 1932.

III Sprawozdanie Izby Rzemieślniczej w Lublinie za rok 1932, Lublin 1933.

101 „Lubliner Sztyme” wychodził w latach 1928-1939, a „Lubliner Tugblat” w latach 1918-1939. Więcej na temat obu tytułów zob.: Adam Kopciowski, Wos hert zich in der prowinc? Prasa żydowska na Lubelszczyźnie i jej największy dziennik „Lubliner Tugblat”, Lublin 2015. 
IV Sprawozdanie Izby Rzemieślniczej w Lublinie za rok 1933, Lublin 1934. V Sprawozdanie Izby Rzemieślniczej w Lublinie za rok 1934, Lublin 1935. VI Sprawozdanie Izby Rzemieślniczej w Lublinie za rok 1935, Lublin 1936. VII Sprawozdanie Izby Rzemieślniczej w Lublinie za rok 1936, Lublin 1937.

VIII Sprawozdanie Izby Rzemieślniczej w Lublinie za rok 1937, Lublin 1938.

„Biuletyn Izby Rzemieślniczej w Lublinie” (1936), nr 3.

„Biuletyn Izby Rzemieślniczej w Lublinie” (1936), nr 6.

„Biuletyn Izby Rzemieślniczej w Lublinie” (1937), nr 6.

Dos bukh fun Lublin: zikhrojnes, gvies-eydes un materyaln ibern lebn, kamf un martirertum fun lubliner Yidiszn yiszew, Pariz 1952.

Drugi powszechny spis ludności z dn. 9. XII 1931 r. Mieszkania i gospodarstwa domowe. Ludność. Stosunki zawodowe. Województwo lubelskie, Warszawa 1938 („Statystyka Polski”, seria C, z. 85, 1938).

Mały rocznik statystyczny 1939, R. 10, Warszawa 1939.

„Rękodzieło i Przemysł” (18 kwietnia 1936), nr 5.

Rocznik polityczny i gospodarczy 1939, Warszawa 1939.

Rozporządzenie Prezydenta Rzeczypospolitej z dnia 7 czerwca 1927 r. o prawie przemysłowem, Dz.U. 1927, nr 53, poz. 468.

Rozporządzenie Prezydenta Rzeczypospolitej z dnia 27 października 1933 r. o izbach rzemieślniczych i ich związku, Dz.U. 1933, nr 85, poz. 638.

„Rzemiosło” 1 (lipiec-wrzesień 1932), z. 3-5.

\section{Opracowania}

Bornstein Izaak, Rzemiosło żydowskie w Polsce, Warszawa 1936.

Duda Stanisław, Rozwój rzemiosła w Lublinie w okresie międzywojennym, „Annales UMCS", Sectio H, Oeconomia 25 (1991), nr 4.

Gliksman Jerzy, Struktura zawodowa i społeczna ludności żydowskiej w Polsce, Warszawa 1930.

Historia Lublina w liczbach, Lublin 2018.

Kierek Aleksander, Rozwój gospodarczy Lublina w latach 1918-1939, [w:] Dzieje Lublina, t. 2, red. Stanisław Krzykała, Lublin 1975.

Kopciowski Adam, Ida Gliksztejn i jej rodzina. Losy do wybuchu wojny, [w:] Ida Gliksztejn, Pamiętnik z czasów wojny. Lublin, wrzesień 1939 - styczeń 1943, wstęp, posłowie i oprac. Adam Kopciowski, Lublin 2017.

Kopciowski Adam, Wos hert zich in der prowinc? Prasa żydowska na Lubelszczyźnie i jej największy dziennik „Lubliner Tugblat”, Lublin 2015.

Przesmycka Natalia, Lublin. Przeobrażenia urbanistyczne 1815-1939, Lublin 2012.

Ptasiński Cecylian, Rzemiosło w Polsce wspótczesnej, Lublin 1934.

Ptasiński Cecylian, Studium o rozmiarach, strukturze, wytwórczości i rozmieszczeniu rzemiost w województwie lubelskim, Lublin 1939.

Radzik Tadeusz, Społeczność żydowska Lublina w międzywojennym dwudziestoleciu. Obraz statystyczny, [w:] Żydzi w Lublinie, t. 1: Materiały do dziejów społeczności żydowskiej Lublina, red. Tadeusz Radzik, Lublin 1995.

Radzik Tadeusz, Żyli z nami, [w:] Lublin w dziejach i kulturze Polski, red. Tadeusz Radzik, Adam A. Witusik, Lublin 1997. 
Rak Baruch Elimelech, Wspomnienia żydowskiego działacza rzemieślniczego, Warszawa 2010.

Wajs Karolina, Wajs Symcha, Fakty $i$ wydarzenia $z \dot{z} y c i a$ lubelskich Żydów, Lublin 1997.

Piotr Sewruk Uniwersytet Marii Skłodowskiej-Curie w Lublinie piotr.sewruk@gmail.com 
